\title{
Osídlení kultury s moravskou malovanou keramikou v Nové Vsi u Oslavan (okres Brno-venkov)
}

\section{Settlement of the Moravian Painted Ware Culture in Nová Ves near Oslavany (Brno-venkov District)}

\author{
Zdeněk Hájek / Alena Humpolová / Alžběta Čerevková
}

\begin{abstract}
Abstrakt
Hlavním cílem článku je prezentovat analýzu keramického materiálu kultury s moravskou malovanou keramikou z lokality Nová Ves u Oslavan - poloha "Kopaniny". Tato lokalita je již dobře známá díky intenzivním dokladům osídlení ze závěru kultury s lineární keramikou - šáreckého stupně. Kultura s moravskou malovanou keramikou zde má ovšem také výrazné zastoupení, což dokládá charakter keramického souboru, čítajícího celkem 2242 kusů. Většina materiálu byla získána během výzkumů a povrchových prospekcí v prủběhu první poloviny 20. století.
\end{abstract}

\section{Klíčová slova}

neolit, lengyelský kulturní complex, kultura s moravskou malovanou keramikou, analýza keramiky

\begin{abstract}
This article deals with the processing of ceramic material from "Kopaniny" site located in the municipality of Nová Ves village. The site is well-known for its the Linear Culture settlement - especially its latest phase called Sarka-type. A large collection of the Lengyel Culture artifacts indicates an existence of a long-standing settlement in this area. Therefore, the aim of this article is to study this ceramic material, namely two thousand two hundred and forty-two fragments, which predominate in the collection. The majority of the collection was found during the excavation and surface survey conducted in the first half of the 20th century.
\end{abstract}

\section{Keywords}

Neolithic, Lengyel Culture, Moravian Painted Ware Culture, ceramic analysis

Předložená práce vznikla za finanční podpory Ministerstva kultury v rámci institucionálního financování na dlouhodobý koncepční rozvoj výzkumné organizace Moravské zemské muzeum (DKRVO, MK000094862). 


\section{1. Úvod}

Doklady aktivit kultury s moravskou malovanou keramikou (dále jen MMK) nejsou na známé neolitické lokalitě u Nové Vsi zastoupeny tak intenzivně, jako v případě kultury s lineární keramikou (dále jen LnK; Jaroš 1972). Přesto bylo na lokalitě získáno značné množství archeologického materiálu, indikujícího existenci pravděpodobně poměrně rozsáhlého, $\mathrm{z}$ hlediska relativní chronologie dlouhodobě využívaného sídliště. Převážnou část souboru tvoří keramika (celkem 2242 kusů), jejíž analýza představuje hlavní náplň předkládané studie. Většina nálezů byla získána v průběhu 20. až 40. let minulého století pomocí sondáží i povrchových sběrů.

\section{Poloha lokality a nástin osídlení}

Lokalizace neolitického osídlení u Nové Vsi, a stejně tak charakter prrírodního prostředí v jeho zázemí, byla již popsána (Hájek - Humpolová - Čerevková 2014, 211-212). Stopy kultury s MMK známe především z polohy „Kopaniny“ (cca 1000 m SZ obce) v těsné blízkosti toku řeky Oslavy. V rámci této trati byla vyčleněna jednotlivá pole, pod kterými byly objeveny relikty lengyelského sídliště v podobě několika zahloubených sídlištních jam. Funerální aktivity nebyly ve zmíněném prostoru prozatím doloženy.

Objevitelem lokality byl známý archeolog-amatér, Vilém Gross (1894-1977), ve své době jeden z největších odborníků na pravěké osídlení Oslavanska. Ten na lokalitě i v jejím blízkém okolí prováděl intenzivní povrchové průzkumy, v některých případech realizoval rovněž exkavaci několika zahloubených objektů. Údaje o jejich přesném počtu a rozmístění nejsou bohužel známy kvưli absenci převážné části průvodní dokumentace (Koštuřik 1977-1978, 78-79). Stejně tak chybí informace o jejich charakteru, případně potenciálním účelu; bohužel neznáme ani celkový počet identifikova- ných objektů. U některých keramických souborů se dochovaly pouze názvy jednotlivých pozemků, respektive jména jejich majitelů (občanů Nové Vsi), v jejichž prostoru byly nálezy učiněny. Jednalo se o minimálně sedm pozemků (polí). Jejich přesnou lokalizaci ani rozlohu není za daných podmínek možné definovat. $\mathrm{Z}$ těchto důvodů nelze o povaze zdejšího osídlení kultury s MMK vyvozovat mnoho závěrů. Pravděpodobně šlo o plochu o rozloze několika set metrů čtverečních; tento prostor však mohl být různě využíván v rámci jednotlivých fází osídlení.

Pavel Koštuřík (1946-1998) v roce 1969 prokopal jednu sídlištní jámu s archeologickým materiálem neolitického stáří na pozemku novoveského občana P. Kočího. Na základě popisu nálezové situace se jednalo o poměrně rozlehlý objekt obsahující materiál kultur s LnK a MMK; jeho výplň byla velmi dobře odlišitelná od okolní půdy. Dle interpretace autora výzkumu se jednalo o superpozici několika jam, dokládající kontinuitu osídlení na lokalitě nejméně od závěru období lidu s LnK do mladšího stupně kultury s MMK (Koštuřłk 1977-78). Z těchto poznatků lze usuzovat, že poloha „Kopaniny“ byla opakovaně osídlována v průběhu celého neolitu, osídlení kultur LnK a MMK se prostorově překrývalo. Pavel Koštuřík na základě vlastních pozorování označil lokalitu jako charakteristickou polohu pro založení neolitického sídliště (Koštuřik 1977-78, 77). Výzkum přinesl cenné, i když poněkud kusé informace o osídlení kulturou s MMK u Nové Vsi. Zároveň se jedná o poslední archeologický výzkum, který na lokalitě proběhl.

\section{Analýza keramiky}

Keramický soubor byl podroben základní kvantitativní analýze využívající především deskriptivní systém numerického kódu vytvořeného kolektivem autorů Podborský - Kazdová - Koštuřík 

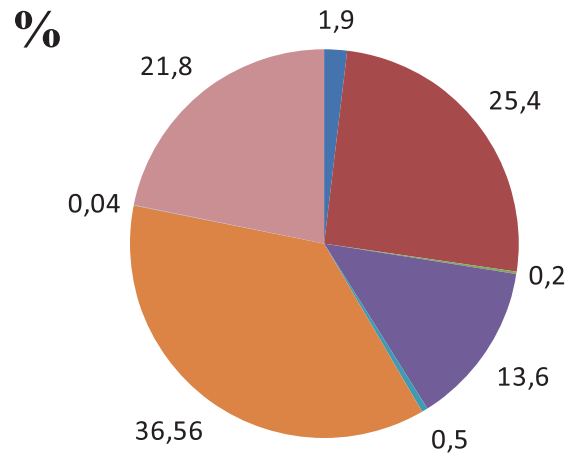

mísy na nožce

- hrnce a ostatní hrncovité nádoby

plastiky

mísy a misky

naběračky

neurčeno

miniaturní nádobky

poháry a pohárky

Graf 1. Nová Ves u Oslavan - „Kopaniny”. Procentuální zastoupení keramických skupin.

Graph 1. Nová Ves u Oslavan - "Kopaniny". Percentage of ceramic groups.

- Weber (1977). Dílčí analýzy nemohly být aplikovány z důvodu chybějících údajů o nálezových situacích, což snižuje vypovídací hodnotu souboru. V prvotní fázi analýzy byl sledován stupeň dochování střepů a velikost fragmentu. V souvislosti s fragmentarizací byla kromě velikosti měřena také síla střepu. U jednotlivých typů fragmentů byly dále sledovány jejich dílčí vlastnosti (tvar a rozměry - průměr okrajů a den). Dále byly sledovány vlastnosti keramické hmoty, a to především její tvrdost, zrnitost a charakter př́iměsí. Zaznamenána byla rovněž úprava povrchu. Bylo identifikováno devět keramických skupin: hrnce, ostatní hrncovité tvary (zahrnující putny, hřibovité nádoby, vázy a kónické nádoby), poháry, pohárky, naběračky, mísy, misky, mísy na nožce a plastiky. Zhruba $36 \%$ jedinců nebylo možné s jistotou blíže přiřadit k žádné keramické skupině. Z určených tvarů převažovaly hrnce a hrncovité tvary, následovala skupina pohárů/ pohárko̊. Hojněji se vyskytly ještě mísy a misky, ostatní skupiny byly zastoupeny výrazně méně. Procentuální zastoupení jednotlivých skupin vyjadřuje graf 1 . Pozornost byla dále věnována především výzdobě a jejímu původnímu umístění na nádobě. Na základě výzdoby, př́ípadně jiných chronologicky citlivých vlastností keramiky (např. profilace hrdel mís), byl soubor datován do jednotlivých fází vývoje kultury s MMK. Kolekci keramiky lze z tohoto hlediska označit za různorodou.

Z hlediska stupně dochování se nejčastěji zachovávaly výdutě (70\%), následovaly okraje $(19,4 \%)$ a dna (4,6 \%). Ojediněle se dochovaly odlomené výčnělky a ucha, části tulejí naběraček, zlomky figurálních plastik. Další kategorii představovaly části nádob (1,2\%). Sem byli zařazeni jedinci, u nichž byl zachován zároveň okraj, dno a profil nádoby. Dále byla vyčleněna kategorie pro případ, kdy byl zachován téměř celý tvar nádoby. Jedná se o naběračku, u které byla odlomena pouze část tuleje. Tato kategorie byla spolu s dalšími typy fragmentů (odlomené ouško, odlomený výčnělek, fragment plastiky, nespecifikovatelný fragment) zahrnuta pod skupinu ostatních fragmentů (viz graf 2).

U okrajů a den byla dále sledována dílčí typologie. V př́ípadě okrajů dominoval zaoblený typ, který byl zároveň nejvíce vázán na keramické skupiny hrnců a hrncovitých nádob, mís/misek a pohárů/pohárků. Dále se vyskytly okraje hrotité, límcovité, seříznuté a rovné. Hrotité okraje se vyskytovaly téměř výhradně u mís a misek, zatímco rovné okraje byly častěji pozorovány 


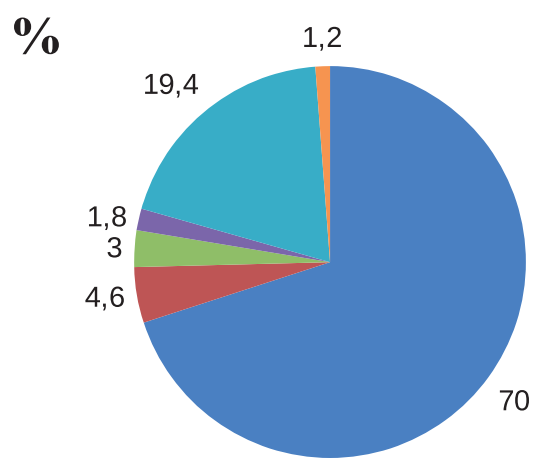

výdut'
dno
hrdlo
ostatní fragmenty
okraj
část nádoby

Graf 2. Nová Ves u Oslavan - „Kopaniny”. Procentuální zastoupení jednotlivých kategorií stupně dochování.

Graph 2. Nová Ves u Oslavan - "Kopaniny". Percentage of individual categories of the degree of preservation.

\begin{tabular}{|l|c|c|c|c|c|c|c|c|c|c|c|}
\hline $\begin{array}{l}\text { Velikostní } \\
\text { kategorie }\end{array}$ & $\mathbf{1}$ & $\mathbf{2}$ & $\mathbf{3}$ & $\mathbf{4}$ & $\mathbf{5}$ & $\mathbf{6}$ & $\mathbf{7}$ & $\mathbf{8}$ & $\mathbf{9}$ & $\mathbf{1 0}$ & $\mathbf{1 1}$ \\
\hline $\begin{array}{l}\text { Velikost } \\
(\mathrm{mm})\end{array}$ & $10 \times 10$ & $20 \times 20$ & $30 \times 30$ & $40 \times 40$ & $50 \times 50$ & $60 \times 60$ & $70 \times 70$ & $80 \times 80$ & $90 \times 90$ & $100 \times 100$ & $100 \times \mathrm{n}$ \\
\hline
\end{tabular}

Tab. 1. Nová Ves u Oslavan - „Kopaniny”. Přehled velikostních kategorií stanovených v rámci studia fragmentarizace keramiky.

Tab. 1. Nová Ves u Oslavan - „Kopaniny”. An overview of size categories defined within the study of pottery fragmentation.

u hrnců a puten; u mís se vyskytovaly o něco méně. Kyjovitý typ byl rovnoměrně zastoupen u hrnců a mís, podobně tomu bylo u seříznutých okrajů, které byly kromě hrnců a mís pozorovány také na pohárech. Límcovité okraje se vyskytly pouze u skupiny hrnců a jiných hrncovitých tvarů. Tento typ okraje se nejčastěji vyskytuje v rámci fáze $\mathrm{Ib}$, př́ípadně IIa, jako tomu bylo např. na lokalitách ve Znojmě-Novosadech či v Hlubokých Mašůvkách. Zde byly límcovité okraje nejvíce vázány na keramickou skupinu hrnců, kromě toho se objevily také u pohárků a mís (Hájek 2013, 101-104). Dna byla nejčastěji ostrá a oblá, ojediněle bez vyznačení. U ostrých i oblých den byl v některých př́ípadech profil dna vklopený dovnitř nádoby, přičemž častěji byl tento prvek pozorován u den ostrých; z hlediska keramických skupin se pak jednalo o pohárky a misky.

\subsection{Fragmentarizace}

V rámci fragmentarizace byla sledována především velikost střepu. Pro účely tohoto pozorování byly stanoveny velikostní kategorie označené 1 až 10 , přičemž kategorie 1 označovala jedince o maximální velikosti $10 \times 10 \mathrm{~mm}$. U střepů přesahujících kategorii 10 byla velikostní kategorie označená hodnotou nejdelší strany (např. pro kategorii 11 se hodnota nejdelší strany rovnala $110 \mathrm{~mm}$; viz tab. 1). Kromě velikosti byla dále měřena síla střepu (v mm), v případě okrajů a den byly zjištovány rovněž hodnoty maximálního průměru. Průměr byl pokud možno změřen také u několika fragmentů nožek ze skupiny nádob mísy na nožce. Průměr hrdel nádob nebylo většinou možné s jistotou změřit kvưli fragmentárnosti materiálu. U artefaktů nepravidelného tvaru byly zjištované rozměry přizpů- 


\section{$\%$}

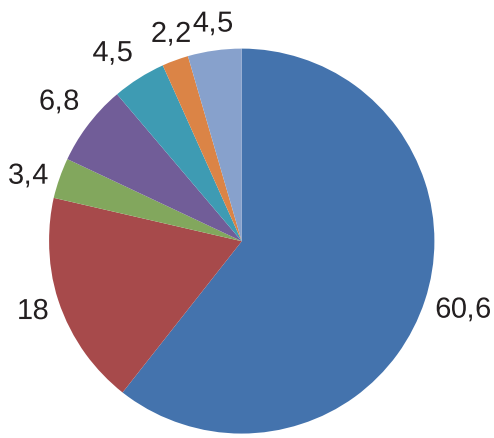

zaoblený
rovný
zaostřený
seříznutý
$\square$ límcovitý
hrotitý
kyjovitý

Graf 3. Nová Ves u Oslavan - „Kopaniny”. Procentuální zastoupení typů okrajů u keramické skupiny hrnců a hrncovitých nádob.

Graph 3. Nová Ves u Oslavan - "Kopaniny". Percentage of rim types in the ceramic group of pots and potshaped vessels.

sobené jejich tvaru, zpravidla byla měřena maximální délka a šířka, případně výška - toto se týká především fragmentů plastik.

\subsection{Hrnce a jiné hrncovité tvary}

Skupinu hrnců a hrncovitých tvarů (celkem $570 \mathrm{ks}$ ) tvořily z hlediska stupně dochování především výdutě, představující téměř $2 / 3$ veškerých zlomků této skupiny. Dále se nejčastěji zachovaly okraje, přičemž jednoznačně dominoval okraj zaoblený (60,6 \%), následovaný okrajem rovným (18\%). Ostatní typy okrajů (zaostřený, seříznutý, límcovitý, kyjovitý a hrotitý) se objevily jen v několika málo případech (viz graf 3). Hodnoty průměru okraje byly značně variabilní, pohybovaly se od 120 do $320 \mathrm{~mm}$, přičemž převažovaly spíše menší rozměry kolem $200 \mathrm{~mm}$. Dna a hrdla tvoří jen malé procento (dohromady $5 \%$ ) fragmentů. Pokud to bylo možné určit, vyskytovala se pouze dna ostrá, v některých případech se však dochovala pouze středová partie této části nádoby a profil dna tedy nebylo možné blíže určit. Průměry den se pohybovaly od 100 do $150 \mathrm{~mm}$, často je však nebylo možné s jistotou změřit. Hrdla byla kónická i rovně posazená.

Keramická hmota na výrobu hrnců a jiných hrncovitých tvarů byla značně různorodá, nicméně převažovala středozrnná, jemnozrnná a zrnitá, o něco méně se vyskytla hmota hrubozrnná a výjimečně také jemná plavená. Do těsta byla hojně přidávána příměs anorganického ostřiva - slídy. Velikost zrnek se pohybovala až do $2 \mathrm{~mm}$. Příměs slídy byla pozorována zhruba u $2 / 3$ střepů této keramické skupiny. Dále byla zaznamenána příměs organického ostřiva ve formě otisků a negativů různých částí rostlin. Hmota s organickou příměsí představovala $5 \%$ z celé kolekce. V několika málo případech byla pozorována také smíšená př́iměs, kdy těsto obsahovalo jak zrnka slídy, tak stopy organických prvků. Hmota byla převážně vypálena do značné tvrdosti (stupeň 5 ), pouze $1 / 4$ vykazovala o něco nižší tvrdost (stupeň 4).

$\mathrm{Z}$ výzdoby u hrncovitých tvarů dominovaly plastické prvky zastoupené některými typy výčnělků. Nejčastěji se vyskytovaly různé varianty polokulovitých výčnělků, mnohdy ze stran zmáčknutých, raná podoba soví hlavičky (prototyp); dále se vyskytla klasická podoba soví 


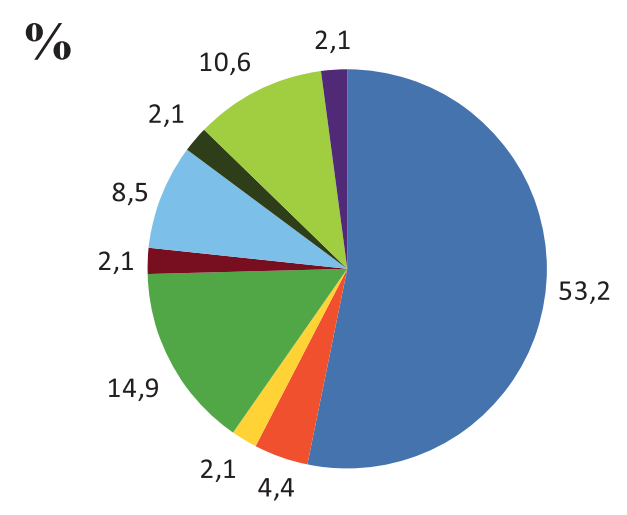

$$
\begin{aligned}
& \text { plastická výzdoba } \\
& \text { žlutočervená malba na vnější i vnitřní } \\
& \text { straně } \\
& \text { červená malba na vnitřní straně } \\
& \text { červená malba na vnější straně } \\
& \text { žlutá malba na vnější i vnitřní straně } \\
& \text { kombinace malované a plastické výzdoby } \\
& \text { vhloubená výzdoba - důlky } \\
& \text { žlutočervená malba na vnější straně } \\
& \text { rýsování }
\end{aligned}
$$

Graf 4. Nová Ves u Oslavan - „Kopaniny”. Procentuální zastoupení typů výzdoby u keramické skupiny hrnců a jiných hrncovitých tvarů.

Graph 4. Nová Ves u Oslavan - "Kopaniny". Percentage of decoration types in the ceramic group of pots and pot-shaped vessels.

hlavičky. Především putny byly ještě opatřeny rohatými uchy. Výčnělky byly nejčastěji aplikovány na výduti, př́ípadně těsně pod okrajem nádob. $\mathrm{V}$ mnoha případech však bylo původní umístění výčnělku neurčitelné z důvodu značné fragmentarizace materiálu. Kromě plastické výzdoby byly na některých jedincích pozorovány relikty malované výzdoby. Nejčastěji se přitom jednalo o kombinaci žluté a červené barvy. Žluto-červená malba se objevila na vnější (obr. 1a) i vnitřní (obr. 1b) straně nádob; samostatné použití červené barvy bylo pozorováno pouze v ojedinělých př́ípadech na vnitřní straně nádob. Samotná žlutá malba se u hrncovitých nádob prakticky nevyskytovala, výjimku představuje pouze jeden fragment výdutě pravděpodobně putny, opatřený z obou stran plošným žlutým nátěrem. V jednom případě byla identifikována červeno-bílá malba a to pouze na vnější straně nádoby (obr. 2). Hnědá malba nebyla zaznamenána. Podobu původních výzdobných motivů a ornamentů nebylo většinou možné určit kvůli fragmentárnosti materiálu. Často zůstaly zachovány pouze jednotlivé žluté nebo červené pásy původního vzoru, především se jednalo o horizontální a vertikální pruhy či jejich kombinace. Ve většině př́ípadů byly barevné pigmenty navíc silně otřelé. Procentuální zastoupení jednotlivých typů výzdoby znázorňuje graf 4 .

Na několika fragmentech byly pozorovány zbytky černé organické hmoty, vyskytující se na vnitřní i vnější straně nádob (obr. 3). Výskyt podobných látek na keramice je obvykle spojován s reparačními procesy; př́ípadně lze uvažovat o užití za účelem zlepšení izolačních vlastností keramiky. Nejčastěji se jedná o březovou smolu, získávanou suchou destilací březové kůry. Využití tohoto adheziva bylo pro období neolitu doloženo již vícekrát (Prokeš et al. 2011, 125-126), v poslední době např. na lokalitách v oblasti jihozápadní Moravy (Mladoňovice, Slavíkovice; Bartík 2015, 122, 156). V některých př́ípadech lze uvažovat rovněž o využití smolné hmoty jako podkladu pro aplikaci výzdobných prvků. Tento fenomén je v posledních letech diskutován zejména v souvislosti s výzdobou lineární keramiky (Vostrovská 2010, 63-65). 


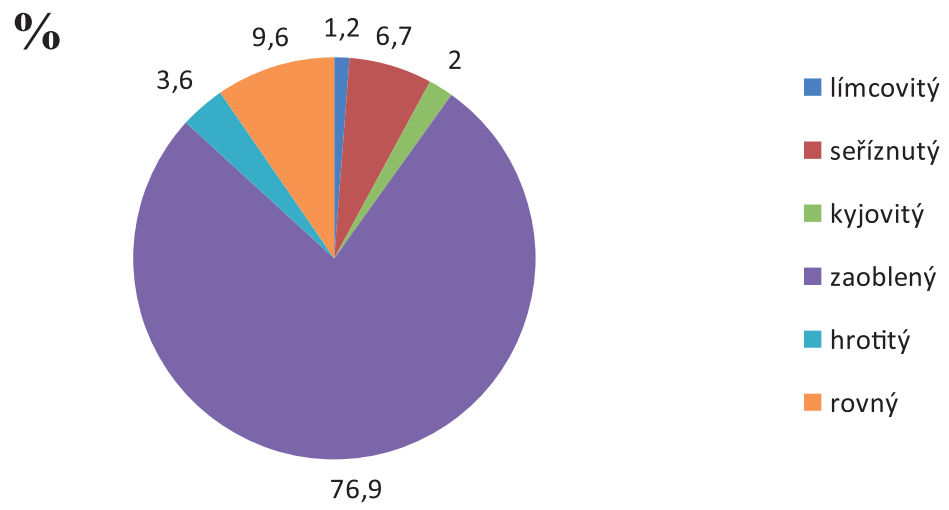

Graf 5. Nová Ves u Oslavan - „Kopaniny”. Procentuální zastoupení typů okrajů u keramické skupiny pohárů a pohárků.

Graph 5. Nová Ves u Oslavan - "Kopaniny". Percentage of rim types in the ceramic group of beakers.

\subsection{Poháry a pohárky}

Poháry a pohárky patří na sídlišti u Nové Vsi, spolu s mísami a hrncovitými nádobami, k nejčastěji se vyskytujícím nádobám. V rámci této skupiny bylo určeno celkem 488 jedinců. Jednalo se přitom o menší i větší tvary, přičemž rozdíl mezi pohárem a pohárkem byl stanoven na základě hodnoty tlouštky střepu: do kategorie pohárků byly řazeny fragmenty, jejichž síla nepřesáhla v místě maximální výdutě (případně jejího zlomu) $5 \mathrm{~mm}$. Střepy o větší tlouštce byly evidovány již jako poháry. Pokud to bylo možné, byly měřeny rovněž hodnoty průměru okraje či dna nádoby. U pohárků dosahovaly průměry den rozměrů 35 až $50 \mathrm{~mm}$ a průměry okrajů 70 až 110 mm. Celkem $32 \%$ jedinců nemohlo být změřeno kvůli fragmentárnosti. Hodnoty pohárů dosahovaly 50 až $70 \mathrm{~mm}$ pro průměry den a 90 až $180 \mathrm{~mm}$ pro průměry okrajů, přičemž nezměřitelných bylo $16 \%$ jedinců. Okraje a dna se u obou velikostních kategorií tohoto typu nádob zachovaly ve stejném poměru, výdutě pocházely častěji z pohárů. Z hlediska fragmentarizace dominovaly v prŕípadě pohárků střepy odpovídající velikostním kategoriím 2 až 4, zatímco fragmenty pohárů spadaly nejčastěji do kategorií 3 až 5 . Tento rozdíl koresponduje s původní velikostí nádob, respektive s jejich konstitucí.

Pro skupinu pohárů a pohárků je příznačná především struktura hmoty - vždy se jednalo o jemně plavené těsto, většinou bez příměsí, případně s příměsí velmi drobných zrnek slídy. Hmota byla vypálena do značné tvrdosti (stupeň 5), mnohdy se však, na rozdíl od jiných keramických skupin, objevil i méně tvrdý výpal (stupně 3 a 4). Také pouze u pohárů a pohárků byla pozorována úprava povrchu leštěním, někdy až do vysokého lesku, dodávajícího nádobě vzhled terry nigry (obr. 4). Tyto nádoby tvořily $2 \%$ z celkového množství jedinců dané skupiny.

U pohárků i pohárů se vyskytly prakticky shodné typy okrajů jako u skupiny hrnců, přičemž jednoznačně dominoval okraj zaoblený (obr. 14: 2-9); ostatní typy byly pozorovány výrazně méně (viz graf 5). Zastoupení typů den bylo rovnoměrné, objevila se dna jak ostrá, tak oblá, u obou typů i mírně dovnitř vklopená, avšak převažovaly rovné varianty. 


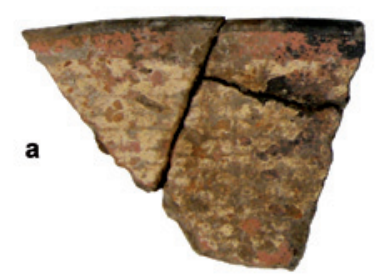

1

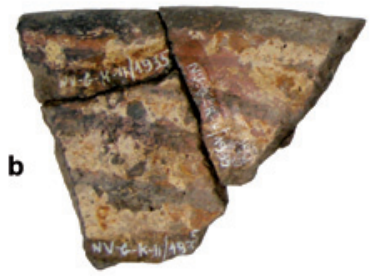

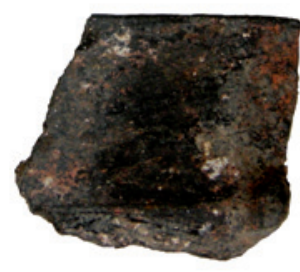

2

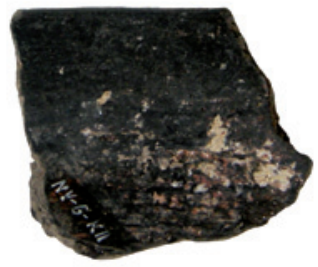

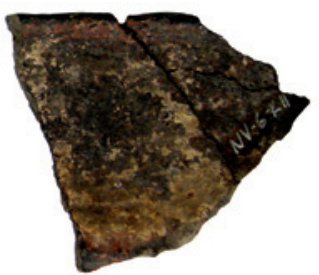

3

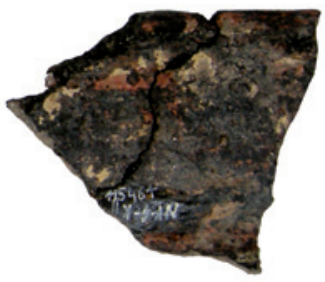

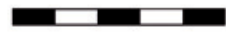

Obr. 1. Nová Ves u Oslavan - „Kopaniny”. Vybrané fragmenty zdobených jedinců ze skupiny hrnců/hrncovitých nádob a mís/misek (foto: A. Čerevková).

Fig. 1. Nová Ves u Oslavan - "Kopaniny". Selected fragments of decorated individuals from the groups of pots/ pot-shaped vessels and bowls (photo: A. Čerevková).

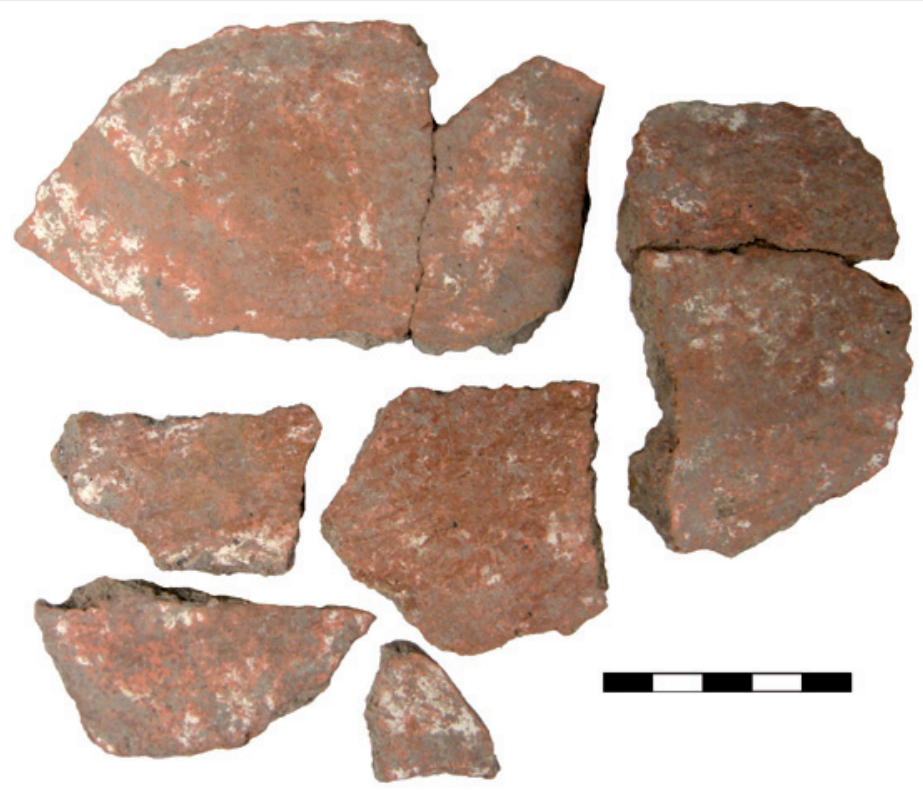

Obr. 2. Nová Ves u Oslavan - „Kopaniny”. Aplikace červeno-bílého plošného nátěru na hrncovité nádobě (foto: A. Čerevková).

Fig. 2. Nová Ves u Oslavan - "Kopaniny". Application of red-white surface paint on a pot-shaped vessel (photo: A. Čerevková). 


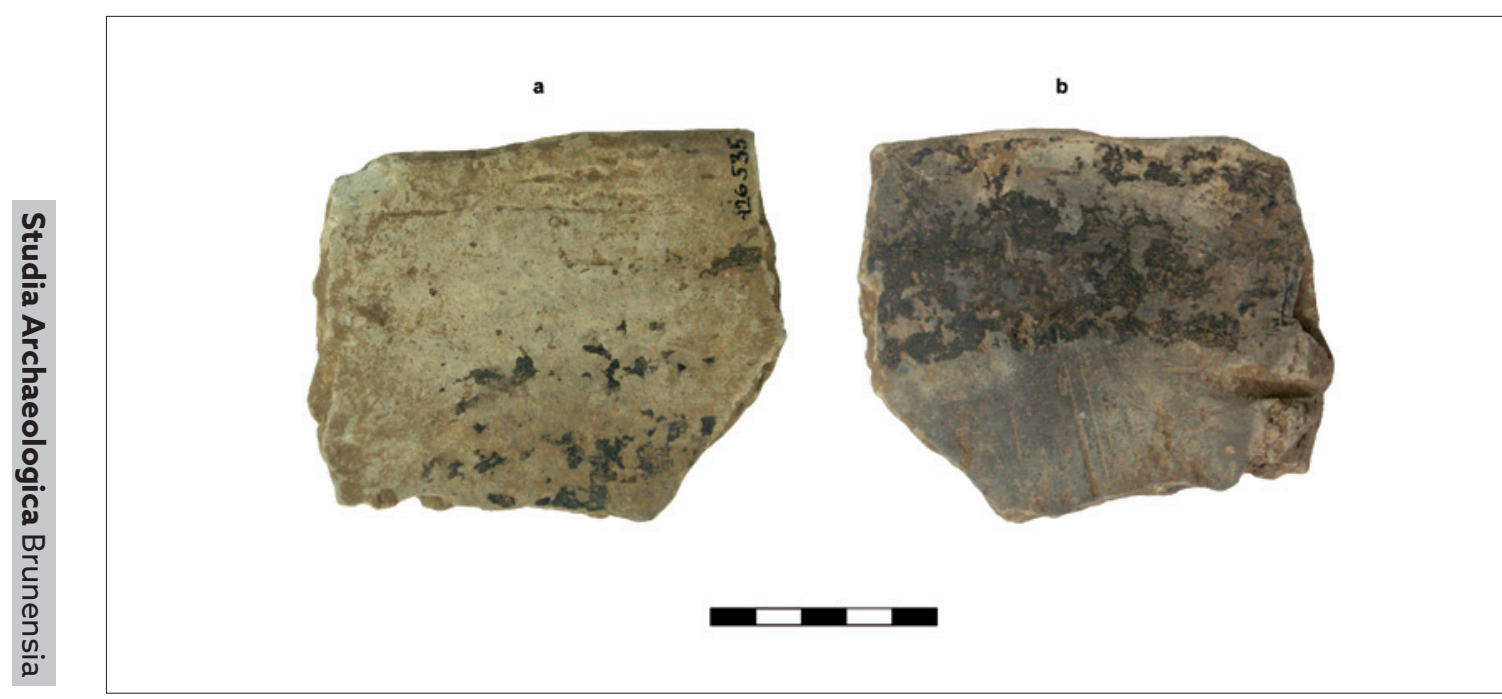

Obr. 3. Nová Ves u Oslavan - „Kopaniny". Aplikace černé smolné hmoty na vnější i vnitřní straně nádoby (foto: A. Čerevková).

Fig. 3. Nová Ves u Oslavan - "Kopaniny". Application of black resinous substance on the external and internal surface of a vessel (photo: A. Čerevková).

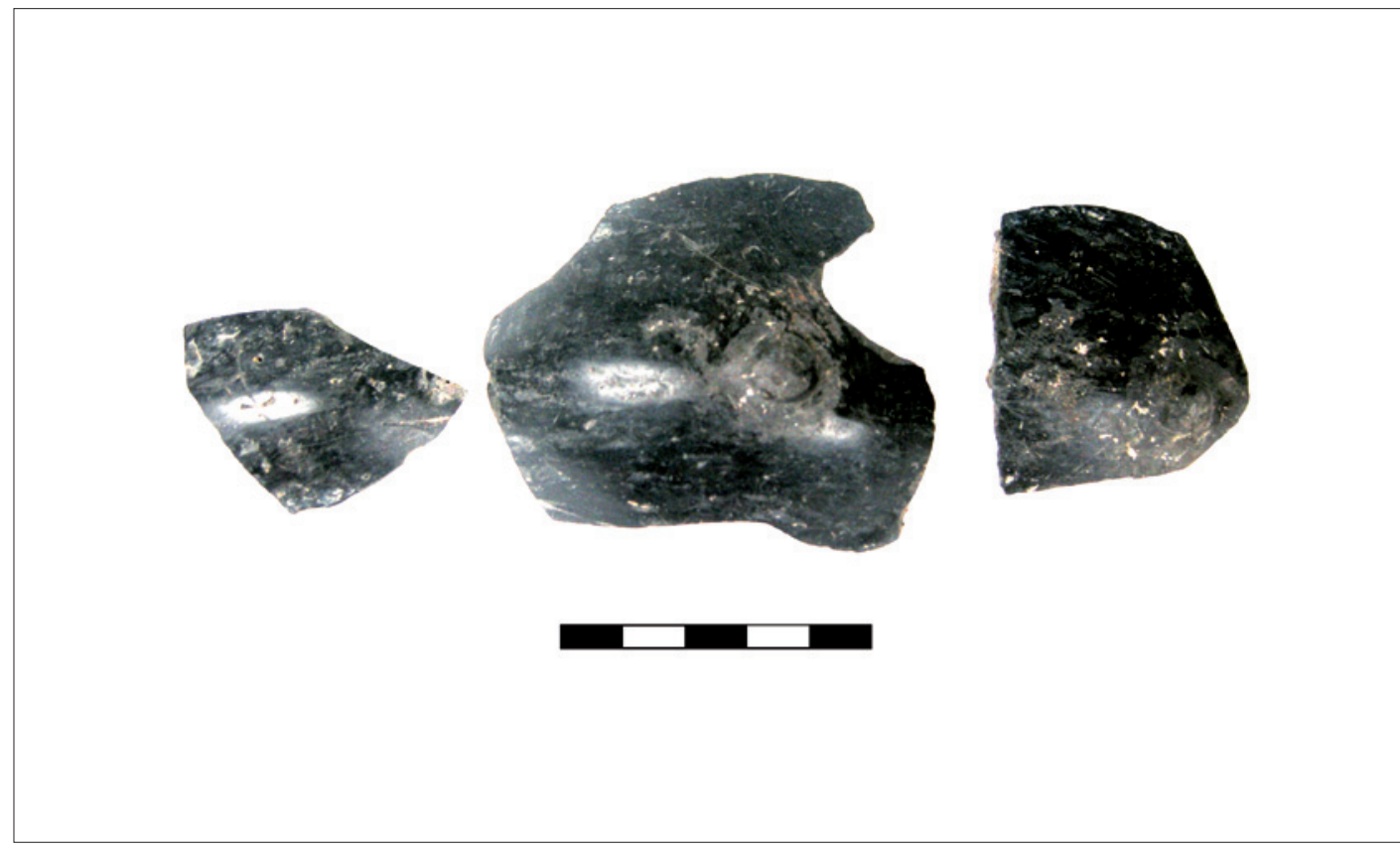

Obr. 4. Nová Ves u Oslavan - "Kopaniny”. Fragmenty z pohárku napodobující vzhled terry nigry (foto: A. Čerevková).

Fig. 4. Nová Ves u Oslavan - "Kopaniny". Fragments of a beaker imitating the appearance of terra nigra (photo: A. Čerevková). 


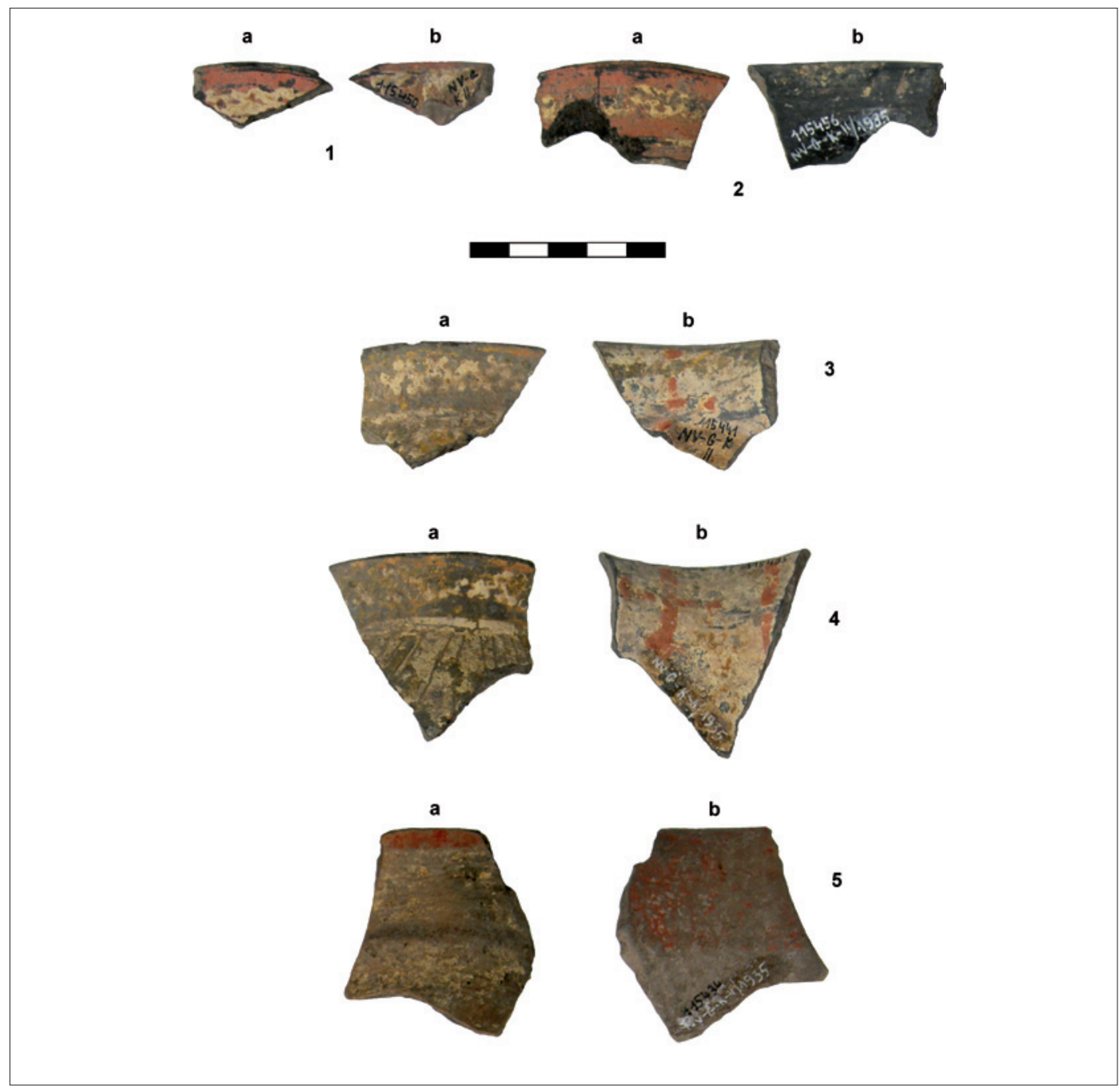

Obr. 5. Nová Ves u Oslavan - „Kopaniny”. Vybrané fragmenty zdobených pohárků (foto: A. Čerevková).

Fig. 5. Nová Ves u Oslavan - "Kopaniny". Selected fragments of decorated beakers (photo: A. Čerevková).

Poháry a pohárky představují keramickou skupinu s nejvyšší mírou zdobení: výzdobu nesla $1 / 4$ všech jedinců. Více než polovina $(55 \%)$ všech zdobených kusů nesla malovanou výzdobu, dalších $20 \%$ připadá na plastickou výzdobu, téměř shodnou měrou pak byla zastoupena rýsovaná (13\%) a kombinovaná (12 \%) výzdoba. Podrobnější zastoupení jednotlivých typů výzdoby zobrazuje graf 6 (v případě výskytu malované výzdoby na obou stranách nádoby je jako první uvedená malba na vnější straně). Malování bylo nejčastěji provedeno žlutou a červenou barvou, respektive jejich kombinací, přičemž, podobně jako u skupiny hrncovitých nádob, byla žlutá barva často použita jako plošný nátěr a vytvářela „pozadí, pro červeně malované vzory (obr. 5: 3b, 4b). Častěji než u hrncovitých nádob byla žluto-červená malba aplikována také na vnitřním povrchu nádoby (obr. 5: 1b). Spolehlivě bylo možné identifikovat výzdobný motiv v podobě žlutých a červených 


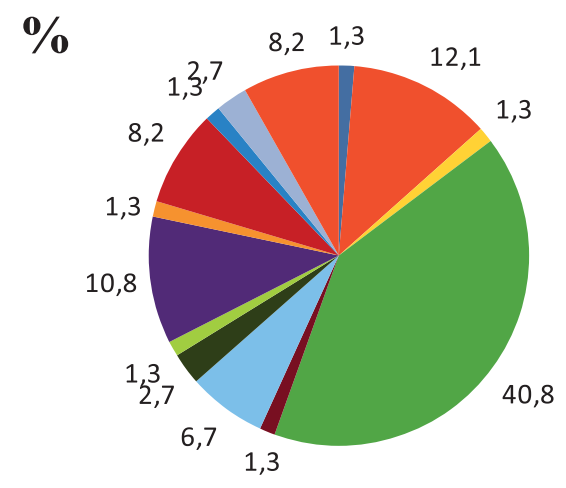

červeno-bílá malba na vnější straně

červená malba na vnější straně

červeno-bílá malba na vnitřní straně

ם žluto-červená malba na vnější straně

- malba na vnější i vnitřní straně - červená, červenožlutá

červená malba na vnitřní straně

žlutá malba na vnější straně

červená malba z obou stran

rýsování

malba na vnější i vnitřní straně - žlutočervená, žlutá

- rýsování v kombinaci s malovanou výzdobou

malba na vnější i vnitřní straně - žlutá, žluto-červená

žlutá malba na vnější i vnitřní straně

kombinace rýsované, malované a plastické výzdoby

Graf 6. Nová Ves u Oslavan - „Kopaniny”. Procentuální zastoupení typů výzdoby u keramické skupiny pohárů a pohárků.

Graph 6. Nová Ves u Oslavan - "Kopaniny". Percentage of decoration types in the ceramic group of beakers.

horizontálních pruhů, aplikovaných při okraji (obr. 5: 2a), případně na výduti nádoby. Ve dvou prrípadech byly dobře patrné vzájemně se protínající červené horizontální i vertikální pruhy na žlutém pozadí - tento motiv se nacházel na vnitřní straně hrdla nádoby (obr. 5: 3b, 4b). Motiv pruhů se vyskytl rovněž v souvislosti se samostatnou žlutou malbou, přičemž tvưrci využili tmavě šedého až černého pưvodního povrchu nádoby jako podkladu. Častější než u skupiny hrnců bylo také použití bílé barvy, vždy v kombinaci s červenou barvou. Nejlépe zachována zůstala tato bichromie na větším poháru, který nesl rovněž plastickou výzdobu; bílá barva je zde plošně rozprostřena na červeném podkladě (obr. 6). Červený monochromní nátěr byl aplikován na vnější i vnitřní (obr. 5: 5b) straně nádoby. Kromě plastických prvků bylo malování kombinováno také s vhloubenou výzdobou - rýsováním. To bylo vždy provedeno velmi tenkými (do $1 \mathrm{~mm}$ ) liniemi a v některých případech sloužilo jako kontura pro aplikaci malby (obr. 7: 1, 2, 4). Původní výzdobný motiv bohužel nebylo možné rekonstruovat. Podobný jev doprovází samostat- nou vhloubenou výzdobu; v tomto případě byl identifikován pouze jeden jedinec nesoucí výzdobu meandru (obr. 7: 5). V ostatních případech tvořilo rýsování šikmé rovné (obr. 7: 3, 7), případně mírně zaoblené pásy (obr. 7: 6). Pravděpodobně se jedná o relikty motivu vícenásobné klikatky (obr. 7: 9), případně různých variant meandrů. Tento typ výzdoby se objevuje ve fázi Ib (Kazdová 1983, 124). V ojedinělém případě bylo rýsování a malování doplněno ještě o plastický prvek - v tomto případě polokulovitý výčnělek opatřený ze stran otvory (obr. 7: 8). Tento typ výčnělku se na pohárcích a pohárech vyskytoval také samostatně, častější však byla drobnější varianta polokulovitého či oválného výčnělku bez otvorů. Kombinace všech typů výzdoby byla velmi ojedinělá.

\subsection{Mísy a misky}

Mísy a misky představovaly třetí nejhojněji se vyskytující typ nádob na lokalitě. Celkem bylo dané skupině přiřazeno 304 jedinců. Odlišení 


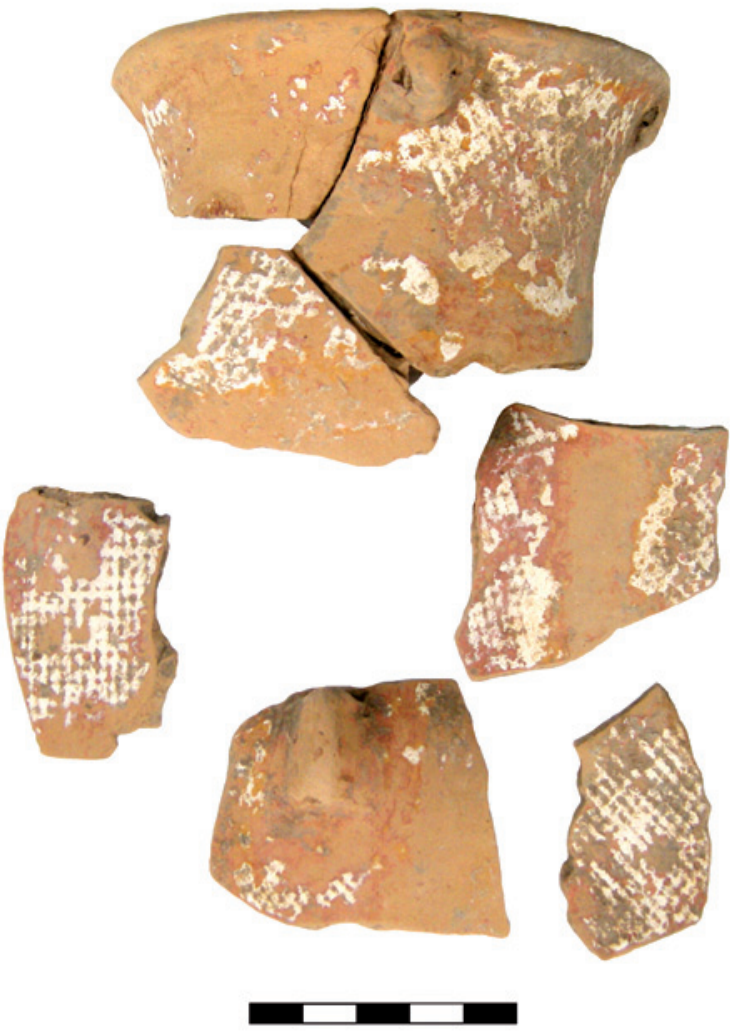

Obr. 6. Nová Ves u Oslavan - „Kopaniny”. Část nádoby s aplikací červeno-bílého plošného nátěru (foto: A. Čerevková).

Fig. 6. Nová Ves u Oslavan - "Kopaniny". Part of a vessel (beaker) with applied red-white surface paint (photo: A. Čerevková).

mís a misek bylo provedeno především na základě dvou rozměrů: průměru okraje a síly střepu. Do kategorie misek byly zařazeny okraje, jejichž průměr nepřesáhl $200 \mathrm{~mm}$, zároveň síla střepu byla menší než $6 \mathrm{~mm}$. Z hlediska stupně dochování se v této kategorii nádob nejčastěji zachovávaly okraje, tvořící více než polovinu všech jedinců (58\%). Ostatní nálezy představují především výdutě; den se zachovalo jen velmi málo. V př́ipadě okrajů jednoznačně dominoval zaoblený typ, následovaný typem rovným, hrotitým a seříznutým. Jiné typy okrajů byly evidovány jen v několika málo kusech (viz graf 7).
Mísy a misky byly nejčastěji vyrobeny z hmoty se středním stupněm zrnitosti (47,3\%), následovala hmota zrnitá (19,2 \%) a jemnozrnná $(19,7 \%)$, o něco méně pak byla použita jemná plavená $(12,3 \%)$ a výjimečně i hrubá zrnitá hmota $(1,5 \%)$. Plavená hmota souvisela s výrobou menších tvarů o menší síle střepu. Povrch nádob byl většinou ohlazen $(64,5 \%)$ či dokonce vyleštěn $(6,9 \%)$, zhruba u jedné čtvrtiny $(27,6$ \%) byl ponechán přirozený, a to i v případě použití výrazně zrnité hmoty (1\%).

Tato keramická skupina nedisponovala př́íliš velkým počtem zdobených kusů, na celou 


\section{$\mathbf{0}$}

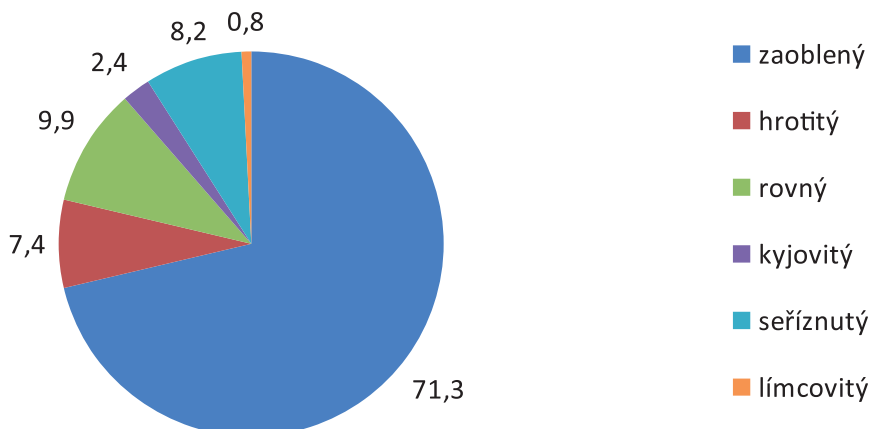

Graf 7. Nová Ves u Oslavan - „Kopaniny”. Procentuální zastoupení typů okrajů u keramické skupiny mís a misek.

Graph 7. Nová Ves u Oslavan - "Kopaniny". Percentage of rim types in the ceramic group of bowls.

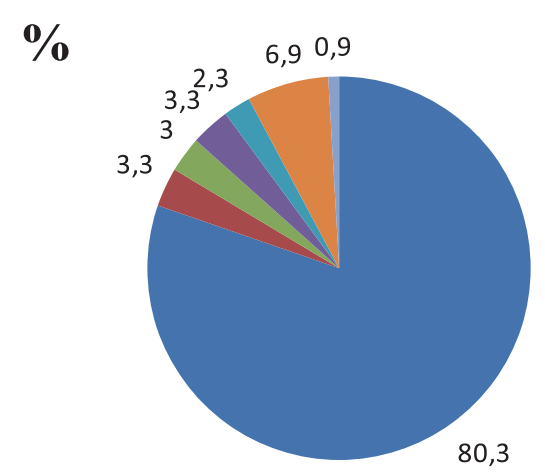

$$
\begin{aligned}
& \text { [ plastická } \\
& \text { žlutá malba na vnější straně } \\
& \text { žlutá malba na vnější i vnitřní straně } \\
& \text { vhloubená } \\
& \text { kombinace plastické a malované výzdoby } \\
& \text { žluto-červená malba na vnější straně } \\
& \text { žluto-červená malba na vnější i vnitřní } \\
& \text { straně }
\end{aligned}
$$

Graf 8. Nová Ves u Oslavan - „Kopaniny”. Procentuální zastoupení typů výzdoby u keramické skupiny mís a misek.

Graph 8. Nová Ves u Oslavan - "Kopaniny". Percentage of decoration types in the ceramic group of bowls.

skupinu připadalo jen zhruba $10 \%$ zdobených jedinců. Výrazně převažovala plastická výzdoba (viz graf 8) provedená formou výčnělků, převážně polokulovitého a oválného typu, který byl často ze stran mírně zploštělý (obr. 12: $1,3,6)$. Ojedinělý nález představuje zoomorfní výčnělek ve tvaru stylizované kozí hlavičky aplikovaný na lomu výdutě menší misky z jemné plavené keramické hmoty. Podobný motiv je znám z mnoha nádob z celého území Moravy. Zoomorfní výčnělky patří v lengyelském okruhu k nejrozšířenějším výtvarným aplikacím (Podborský 1985, 138). Malovaná výzdoba byla provedena žlutou a červenou barvou, v některých př́ípadech na obou stranách nádoby, dále se objevila žlutá malba, a to bud' na vnější nebo vnitřní straně, popřípadě oboustranně. Vyskytla se rovněž kombinace malované a plastické výzdoby.

Typologicky byly nejčastěji přítomny mísy s prohnutými, mírně až extrémně rozevřenými plecemi (obr. 13: 8-10); u plecí bylo v některých př́ípadech patrné zesílení. Tento prvek vykazuje určitou chronologickou citlivost, nebot’ se objevuje především v souborech datovaných do mladšího stupně vývoje kultury 


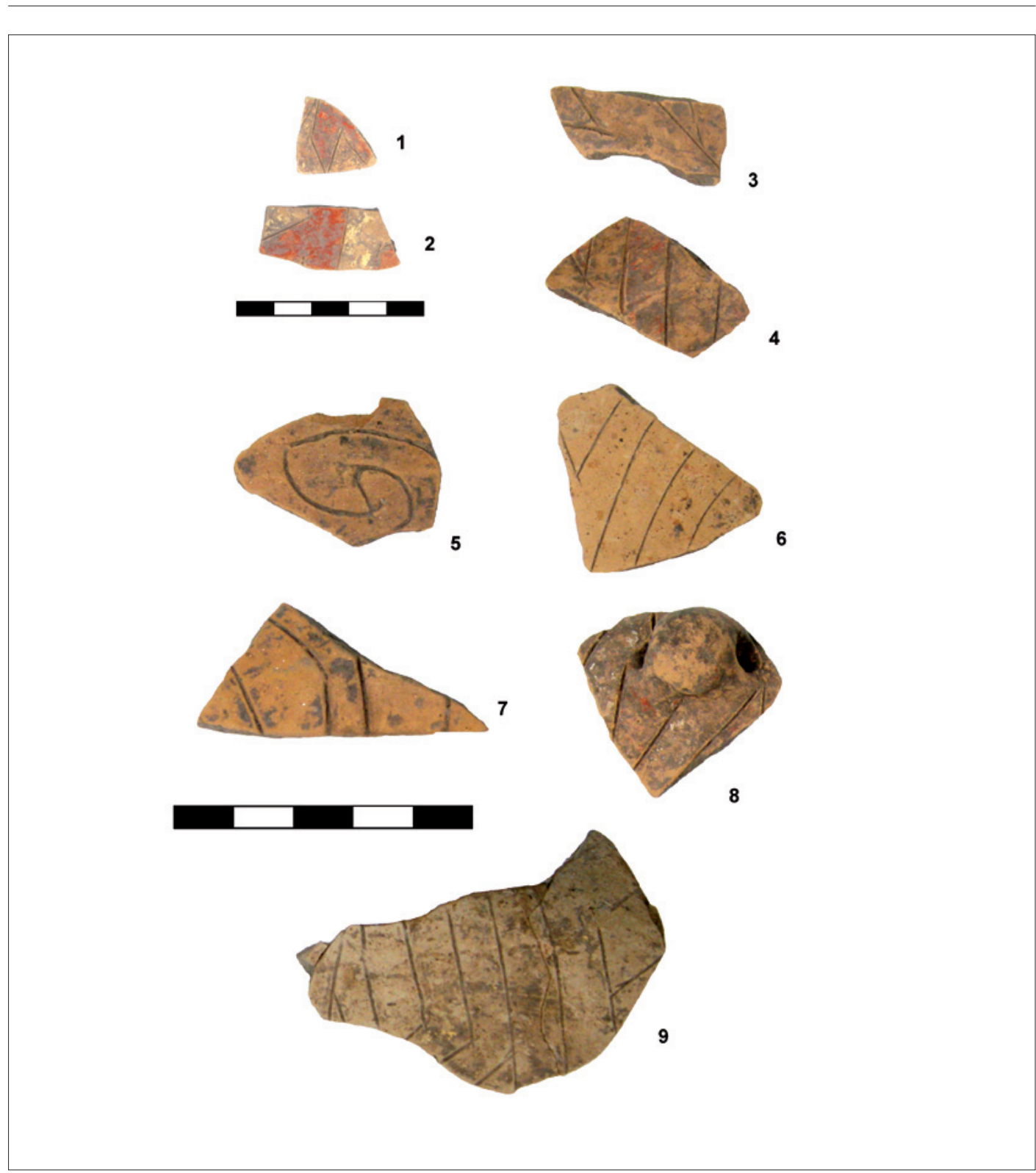

Obr. 7. Nová Ves u Oslavan - „Kopaniny”. Vybrané fragmenty zdobených pohárků (foto: A. Čerevková).

Fig. 7. Nová Ves u Oslavan - "Kopaniny". Selected fragments of decorated beakers (photo: A. Čerevková). 

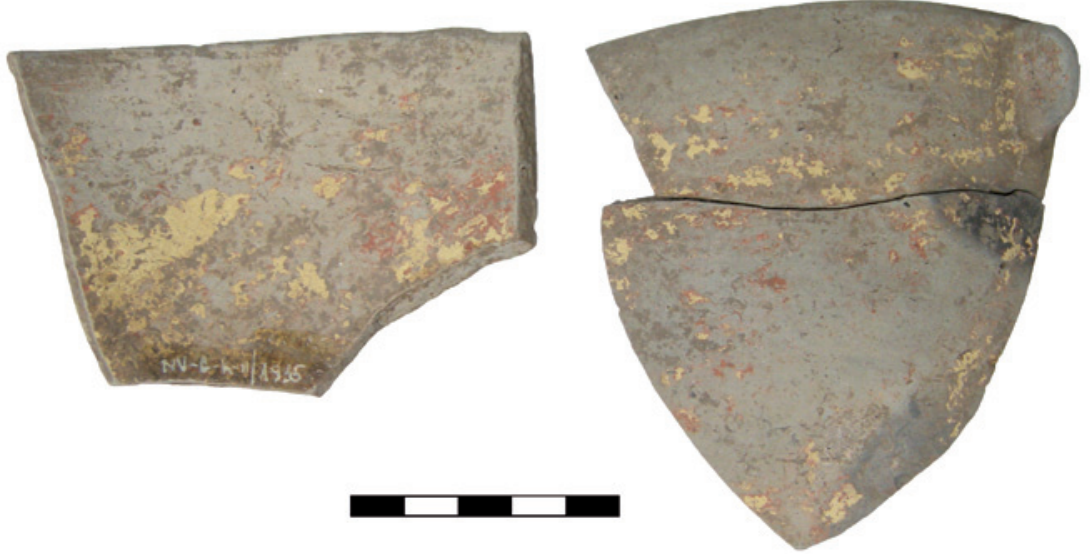

Obr. 8. Nová Ves u Oslavan - „Kopaniny”. Vybrané fragmenty zdobených misek (foto: A. Čerevková).

Fig. 8. Nová Ves u Oslavan - "Kopaniny". Selected fragments of decorated bowls (photo: A. Čerevková).

s MMK (Koštuřrik 1983) Ojediněle se objevily také vyšší kónické misky, z nichž jedna nesla relikt žluto-červené malby, a to $\mathrm{z}$ vnější i vnitřrní strany (obr. 8).

\subsection{Mísy na nožce}

Mísy na nožce byly zachovány podstatně méně než předchozí kategorie mís a misek. Tento jev může být částečně způsoben tím, že pokud nezůstane zachována partie přechodu mísy v nožku či nožka samotná, je mnohdy obtížné odlišit mísu na nožce od běžné mísy. $\mathrm{S}$ jistotou bylo do této skupiny zařazeno celkem 44 jedinců. Z tohoto množství bylo evidováno celkem deset fragmentů zachycujících přechod dna v nožku, ostatní jedinci reprezentují zlomky výdutí a okrajů. Dvakrát byl zachován fragment těla nožky; v obou př́padech se jednalo o nožku kónickou. Povrch jedné z těchto nožek byl upraven leštěním, pravděpodobně ve snaze dosáhnout efektu terry nigry.

Pro výrobu mís na nožce byl použit jemnozrnný, středozrnný i zrnitý materiál, často s př́íměsí slídy. Podle velikosti dochovaných frag- mentů (převážně velikostní kategorie 8 až 14) a síly střepu (7 až $11 \mathrm{~mm}$ ) lze usuzovat, že se původně jednalo o poměrně robustní nádoby velkých rozměrů. S touto domněnkou koresponduje zjištěný průměr jediného dochovaného okraje v této kategorii, který dosáhl hodnoty $350 \mathrm{~mm}$. Zjištěné průměry nožek se pohybovaly mezi 90 a 150 mm. Na jednom z fragmentů byl rozpoznán negativ po odlomeném výčnělku, ostatní byly bez výzdoby. Mísy na nožkách patřily $\mathrm{k}$ málo zdobenému typu nádob také např̀. na sídlišti ve Znojmě-Novosadech či Hlubokých Mašůvkách (Hájek 2013, 197).

\subsection{Naběračky}

Naběračky byly v Nové Vsi - „Kopaninách“ zastoupeny v celkem jedenácti kusech. Jednalo se o fragmenty okrajů (6 ks), tulejí (3 ks) a výdutě (1 ks). Jeden jedinec představoval téměř kompletní tvar s odlomenou horní částí tuleje (obr. 9). Typologicky jej lze přiřadit $\mathrm{k}$ naběračkám s krátkou vodorovně nasazenou tulejí. Tento způsob nasazení tuleje na tělo naběračky bývá na lokalitách zastoupen častěji než nasazení 

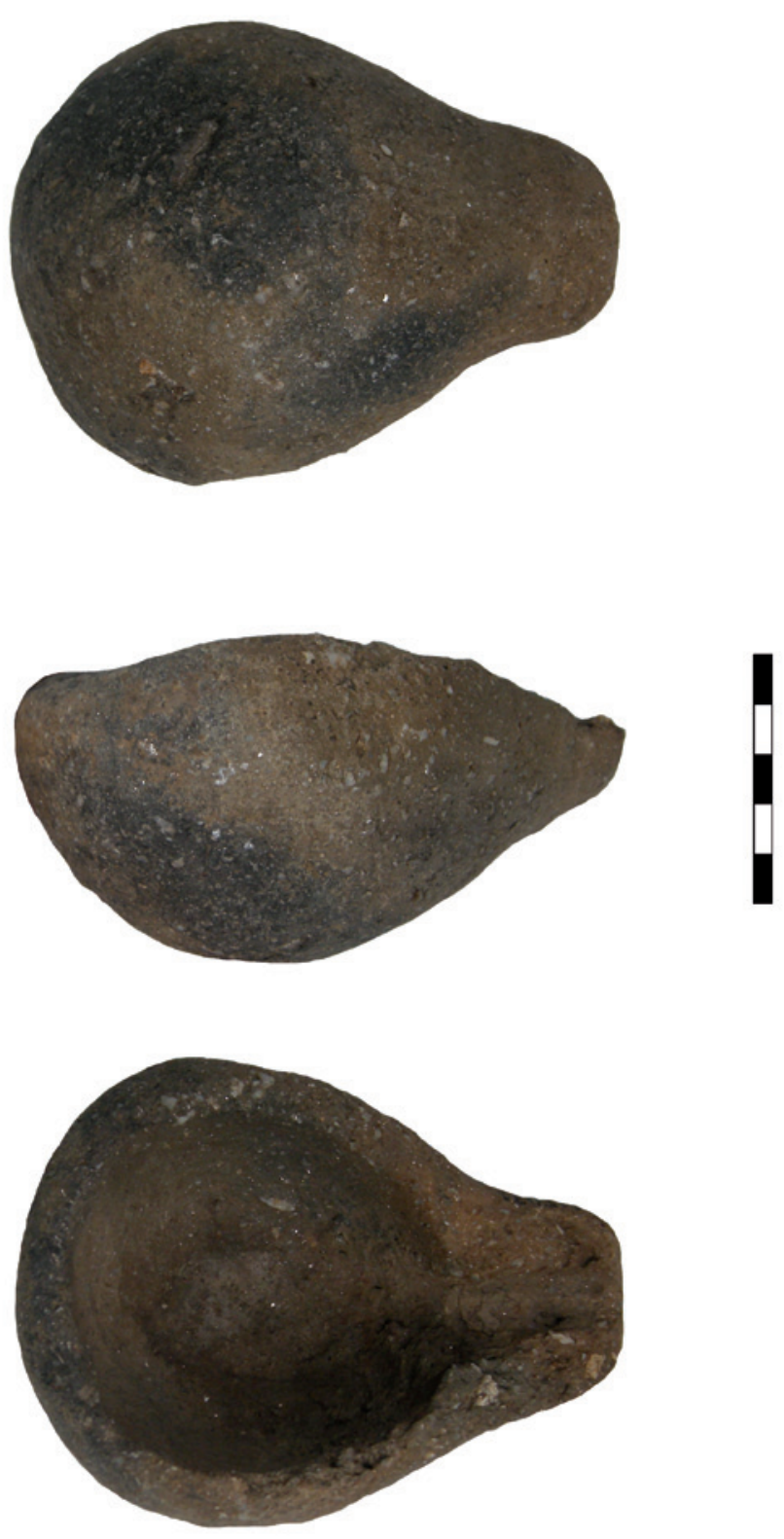

Obr. 9. Nová Ves u Oslavan - „Kopaniny". Téměř kompletně zachovaná naběračka s krátkou vodorovně nasazenou tulejí (foto: A. Čerevková).

Fig. 9. Nová Ves u Oslavan - "Kopaniny". An almost completely preserved shape of a ladle with short horizontal socket grip (photo: A. Čerevková). 


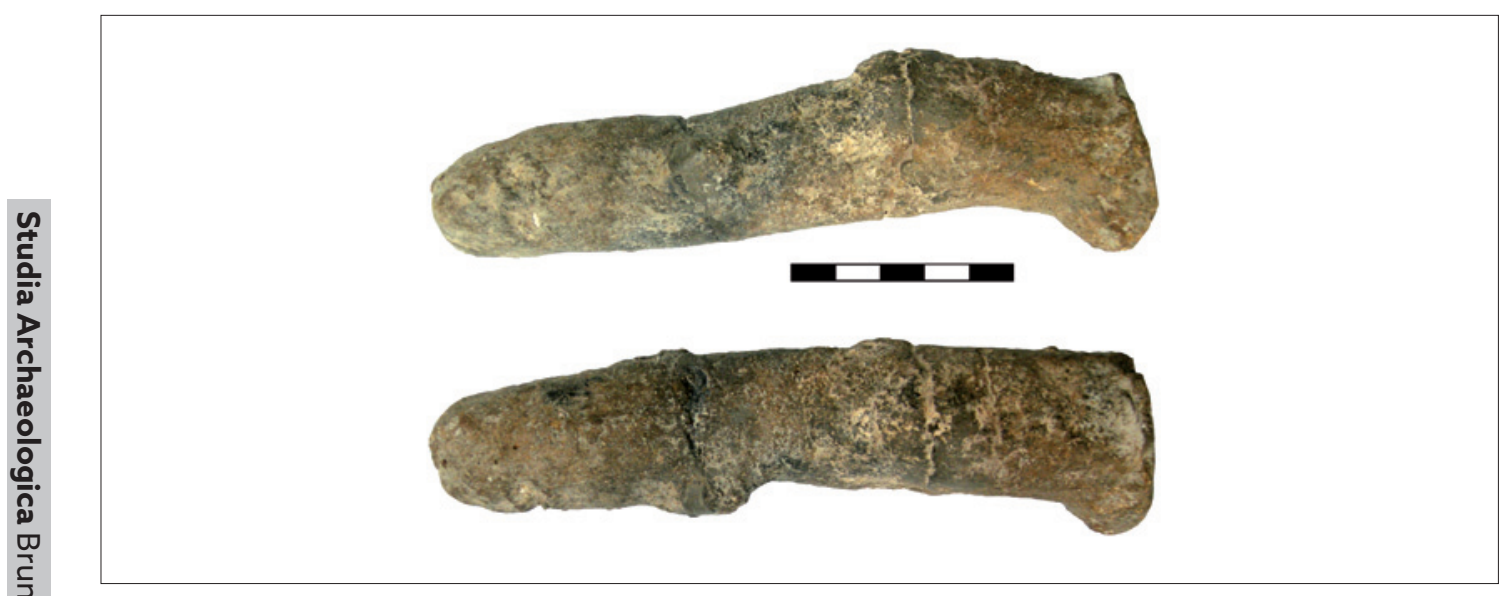

Obr. 10. Nová Ves u Oslavan - „Kopaniny". Plastika představující odlomený falus (foto: A. Čerevková).

Fig. 10. Nová Ves u Oslavan - "Kopaniny". A clay object representing broken-off phallus (photo: A. Čerevková).

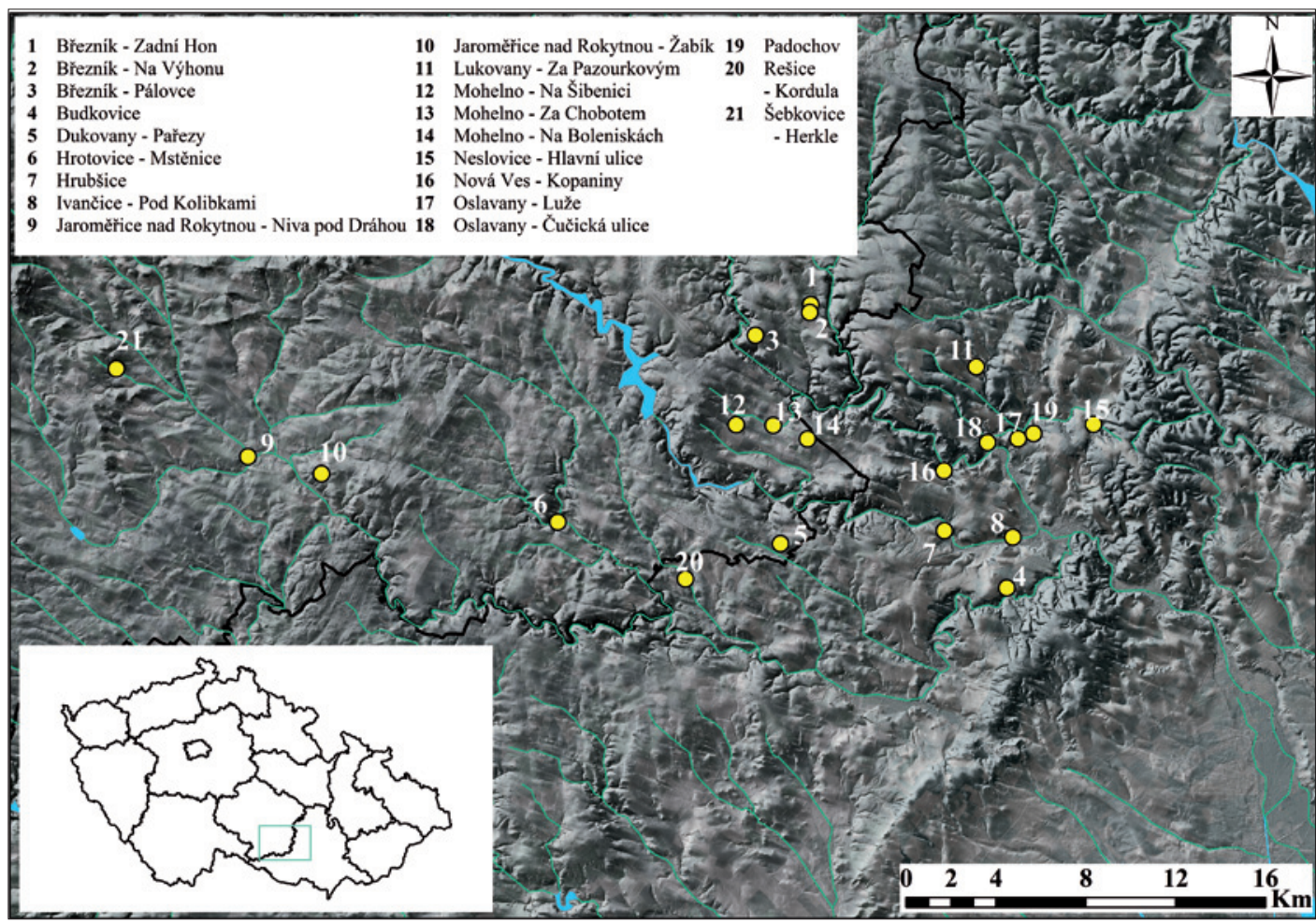

Obr. 11. Nová Ves u Oslavan - „Kopaniny". Mapka osídlení lokalit kultury s MMK v okolí zájmového sídliště (digitalizace: H. Koubková).

Fig. 11. Nová Ves u Oslavan - "Kopaniny". Distribution map of settlements of the Moravian Painted Ware Culture in the neighbourhood of the settlement site under review (digitization: H. Koubková). 

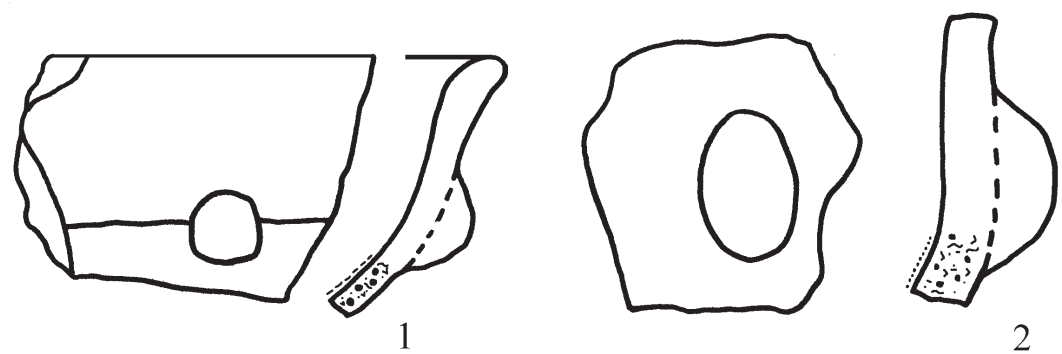

2
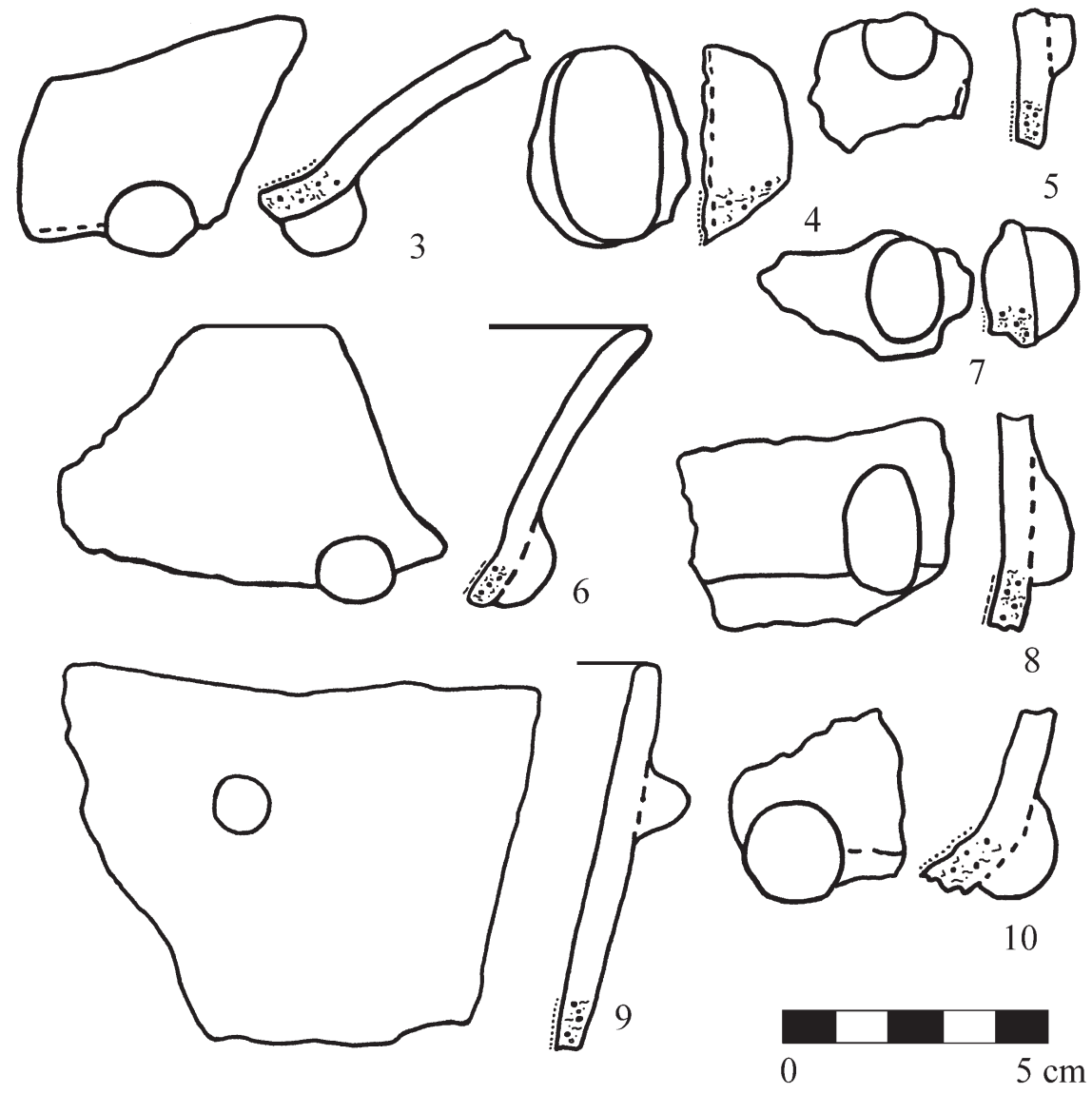

Obr. 12. Nová Ves u Oslavan - „Kopaniny”. Výběr keramického materiálu (kresba: A. Čerevková, H. Koubková).

Fig. 12. Nová Ves u Oslavan - "Kopaniny". Selection of ceramic finds (drawing: A. Čerevková, H. Koubková). 


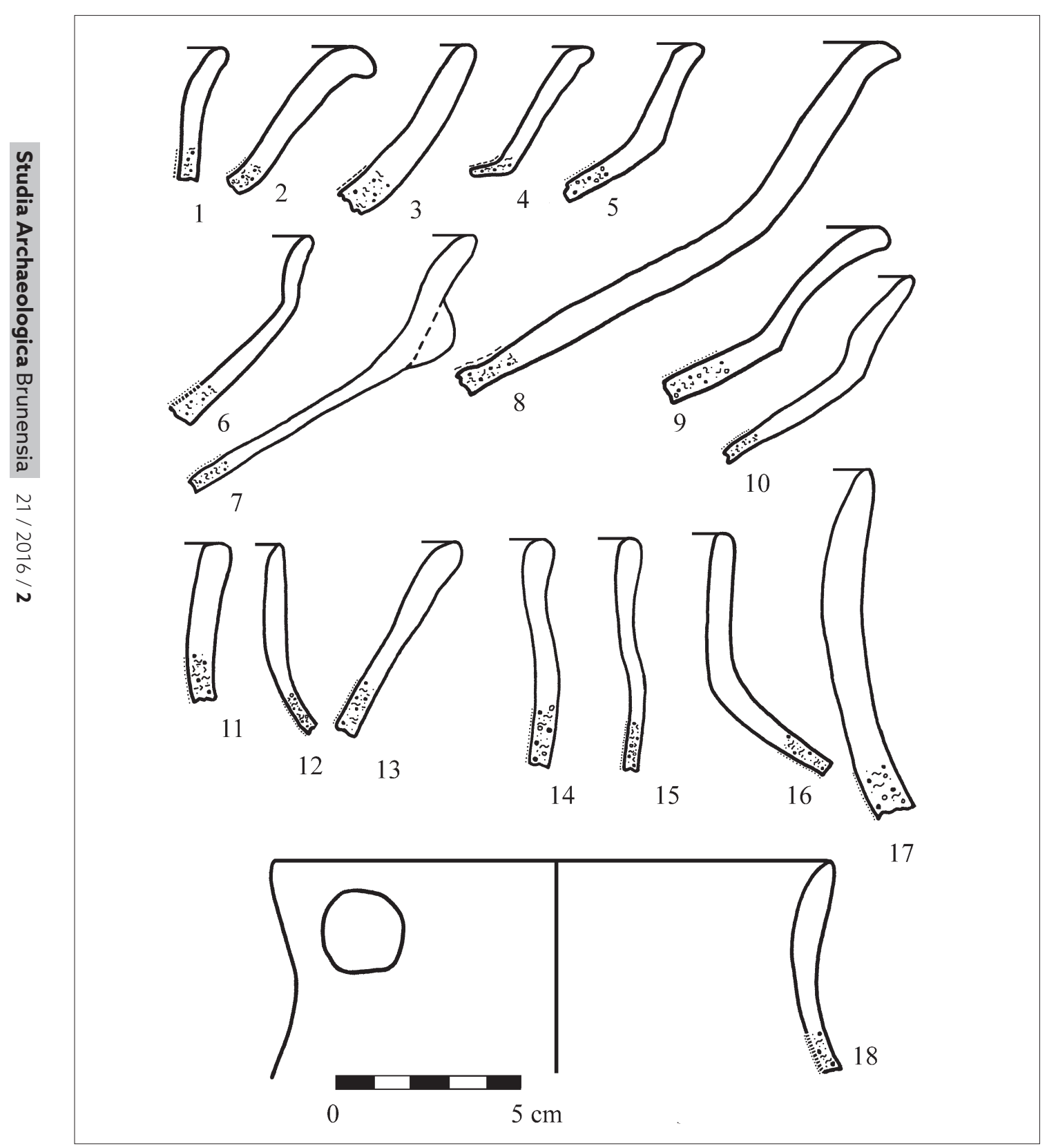

Obr. 13. Nová Ves u Oslavan - „Kopaniny”. Výběr keramického materiálu (kresba: A. Čerevková, H. Koubková). Fig. 13. Nová Ves u Oslavan - "Kopaniny". Selection of ceramic finds (drawing: A. Čerevková, H. Koubková). 
šikmé, které známe např. ze sídliště v Jaroměřicích nad Rokytnou nebo Těšeticích-Kyjovicích (Langweilová 2008, 46; Koštuřı́ 1979). Z hlediska fragmentarizace se naběračky dochovaly ve větších kusech (kategorie „část nádoby,), ve třech prrípadech pak byla zachována pouze část tuleje. Průměr okraje bylo možné změřit pouze u tří kusů; tento rozměr dosahoval hodnot 60 až $90 \mathrm{~mm}$. Typologicky se vždy jednalo o zaoblené okraje. Průměry den nebylo možné změřit - dna byla vždy bez vyznačení. Spolehlivé měření nebylo možné provést ani u fragmentů tulejí, nebot' se jednalo o velmi malé zlomky. Pravděpodobně se jednalo rovněž o krátký typ tuleje. Všechny naběračky byly vyrobeny ze středozrnného až zrnitého materiálu s příměsí slídy. Povrch nedoznal žádných speciálních úprav ani výzdoby. Ojedinělé nálezy malovaných naběraček pocházejí např. z Hlubokých Mašůvek (Hájek 2013, 206), může se však objevit i vhloubená výzdoba - takové exempláře jsou známy z Těšetic-Kyjovic (Langweilová 2008, 49) či Hnánic u Znojma, odkud pochází unikátní naběračka s píchanou výzdobou (Kovárnik 2005, 163).

\subsection{Miniaturní nádobky}

Do této skupiny lze přiřadit pouze jeden exemplář, a to drobnou blíže nespecifikovanou výdut (velikostní kategorie 3) o síle $4 \mathrm{~mm}$ vyrobenou z jemnozrnného těsta. Daný jedinec nenesl stopy výzdoby.

\subsection{Plastiky}

Do této kategorie byly zařazeny fragmenty antropomorfní volné a aplikované (?) plastiky v počtu pěti jedinců. $\mathrm{V}$ prvním případě se jedná o zlomek lidské, s největší pravděpodobností ženské plastiky. Fragment zachycuje dolní končetiny postavy zhruba od poloviny lýtek.
Končetiny jsou po celé dochované délce spojeny v jeden celek, na zlomu horní části je však patrné, že se výše směrem k trupu oddělovaly. Chodidla a nárty jsou poměrně robustní, kotníky byly zdůrazněné formou drobných plochých výčnělků. Plastika byla vyrobena z jemnozrnného materiálu, povrch byl hlazený. Případné stopy malby ani jiného výzdobného prvku nebyly identifikovány. Rozměry fragmentu plastiky činí $35 \times 35 \times 31 \mathrm{~mm}$. Z daného úlomku nelze bohužel s jistotou určit, o který ze základních typů ženských figurálních plastik kultury s MMK se jedná. Znázornění kotníků drobnými pupíky se objevuje již od fáze Ia, partie chodidel však získává na robustnosti až ve fázi Ib a přežívá do II. stupně (Podborský 1983, 36, 41, 51). S jistotou lze tedy říci, že fragment plastiky nenáleží nejstarší fázi kultury s MMK.

Další tři zlomky plastiky představují blíže neurčitelné fragmenty - mohlo by se jednat o relikty paží ženské plastiky mladšího stupně („mašůvecký“, případně „štěpánovický“ typ), nelze však vyloučit také jejich původní umístění na antropomorfní nádobě, jaké známe např. ze Svodína (Němejcová-Pavúková 1998). Tyto plastiky byly vyrobeny ze středozrnného těsta s příměsí slídy, tedy z hmoty odpovídající převážně hrncovitým nádobám nalezeným na lokalitě. Jejich délky se pohybují v rozpětí 40 a $50 \mathrm{~mm}$, šíře pak mezi 15 a $25 \mathrm{~mm}$. Pro spolehlivější interpretaci jsou však jedinci přiliš fragmentární.

Poslední jedinec této keramické skupiny svým tvarem nejvíce připomíná odlomený falus (obr. 10). Jedná se o předmět válcovitého tvaru o délce $158 \mathrm{~mm}$ a maximální šířce 35 mm. Na jeho výrobu byla použita středozrnná hmota bez příměsí a povrch byl hrubě hlazen. Při zaobleném konci je opatřen dvěma protilehlými trojicemi mělkých důlků. Při odlomeném konci je patrné určité rozšíření. Předmět mohl být původně upevněn k podložce, případně tělu nádoby, nelze však vyloučit i jiný způsob jeho ukončení. Analogických nálezů 

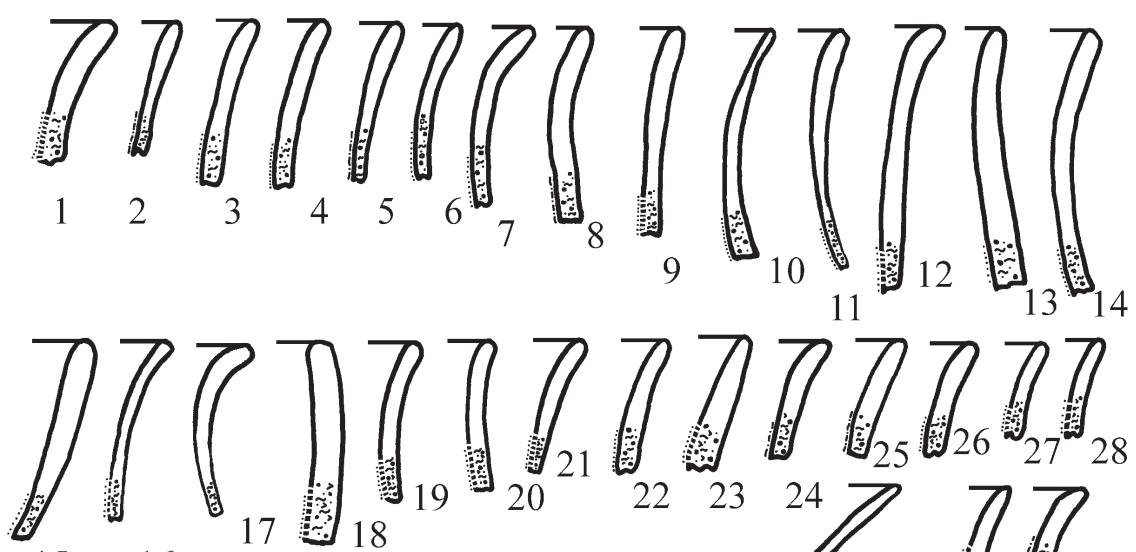

15
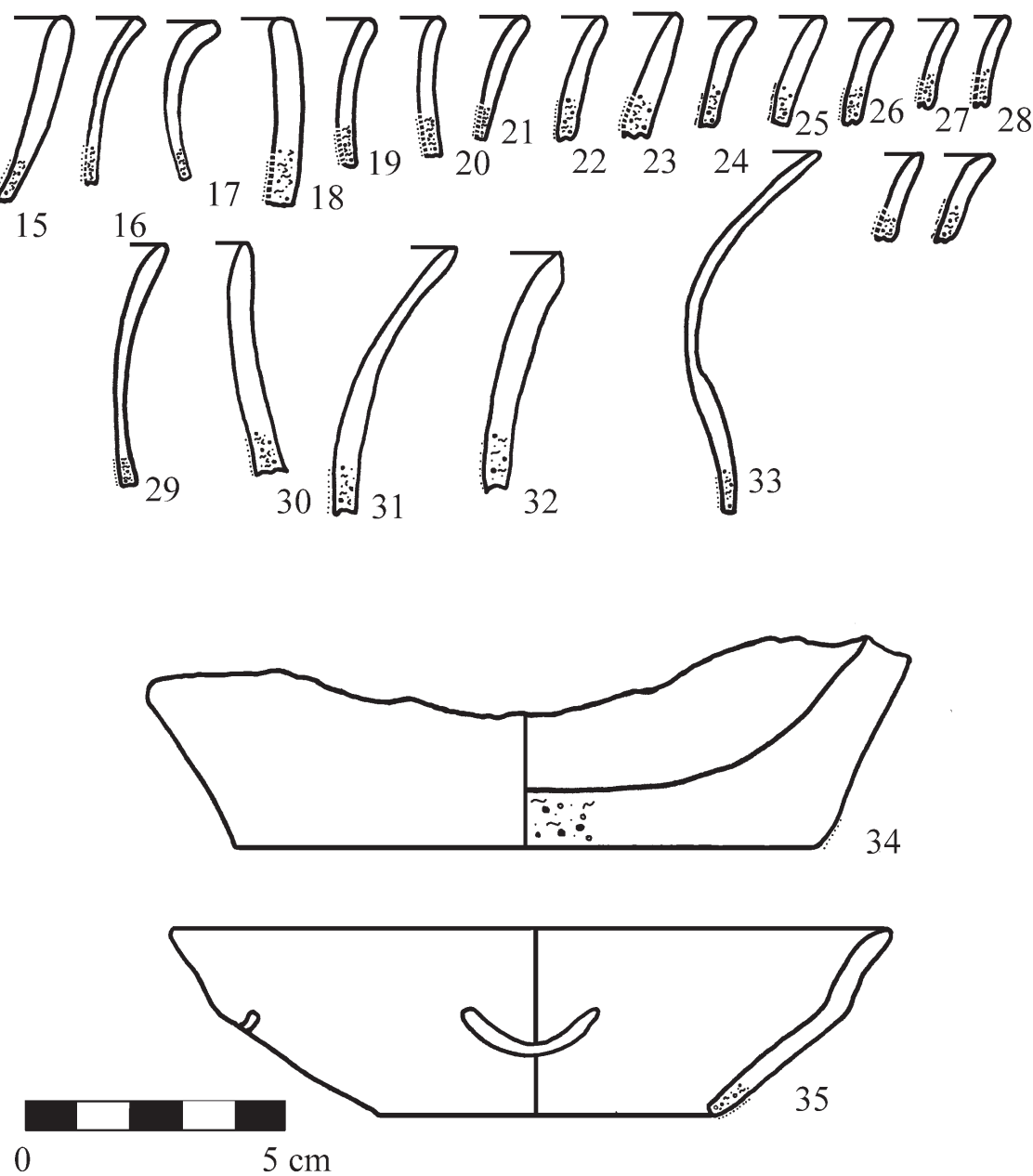

Obr. 14. Nová Ves u Oslavan - „Kopaniny”. Výběr keramického materiálu (kresba: A. Čerevková, H. Koubková).

Fig. 14. Nová Ves u Oslavan - "Kopaniny". Selection of ceramic finds (drawing: A. Čerevková, H. Koubková). 

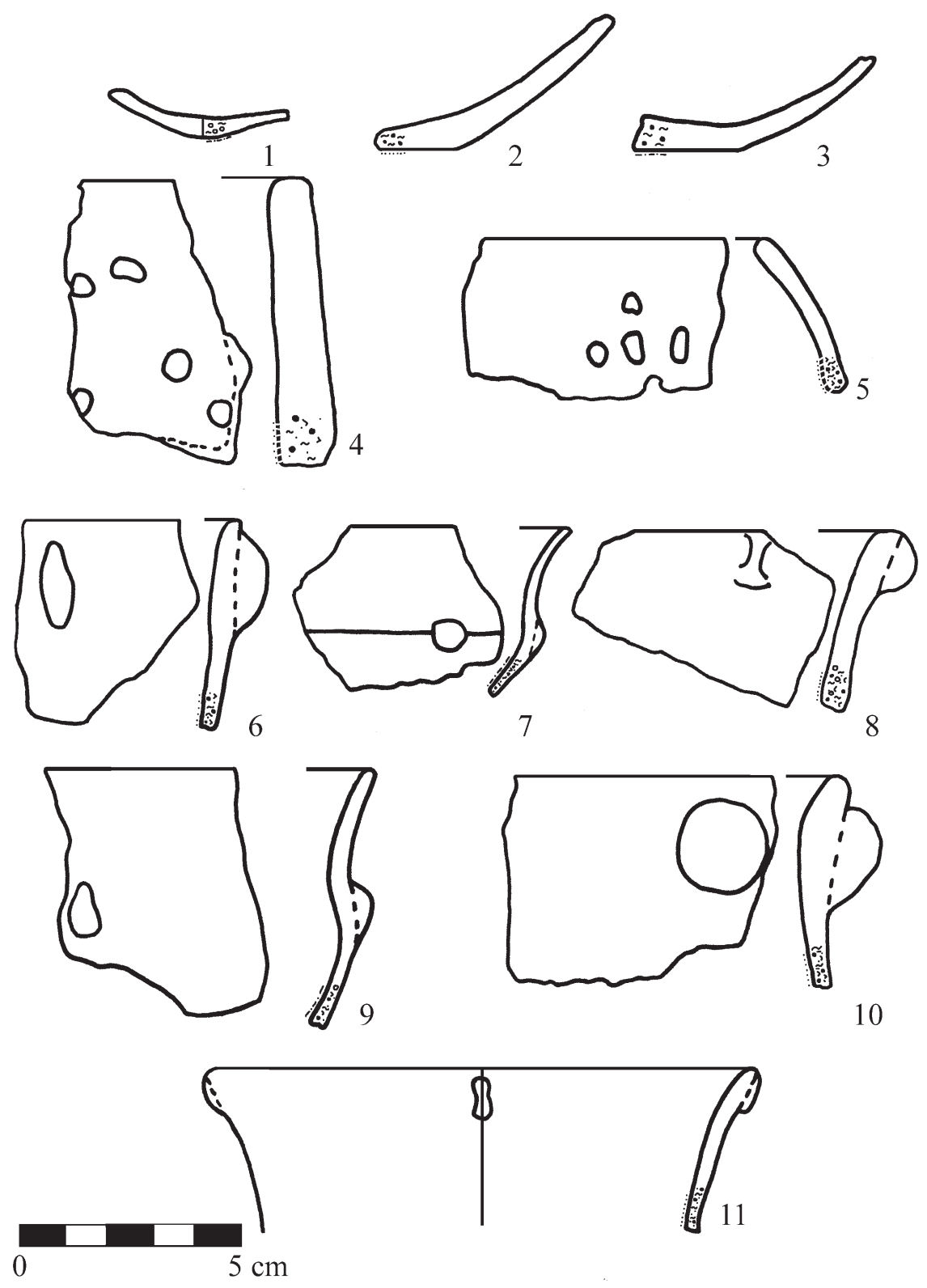

Obr. 15. Nová Ves u Oslavan - „Kopaniny”. Výběr keramického materiálu (kresba: A. Čerevková, H. Koubková).

Fig. 15. Nová Ves u Oslavan - "Kopaniny". Selection of ceramic finds (drawing: A. Čerevková, H. Koubková). 

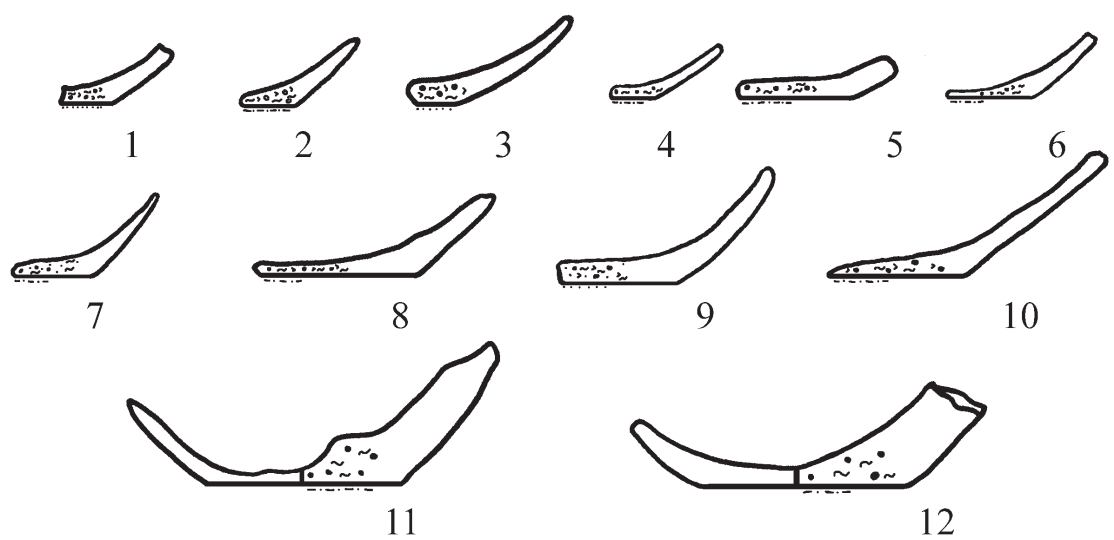

9

10

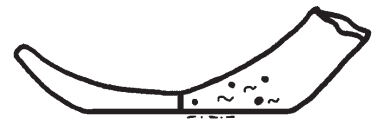

12

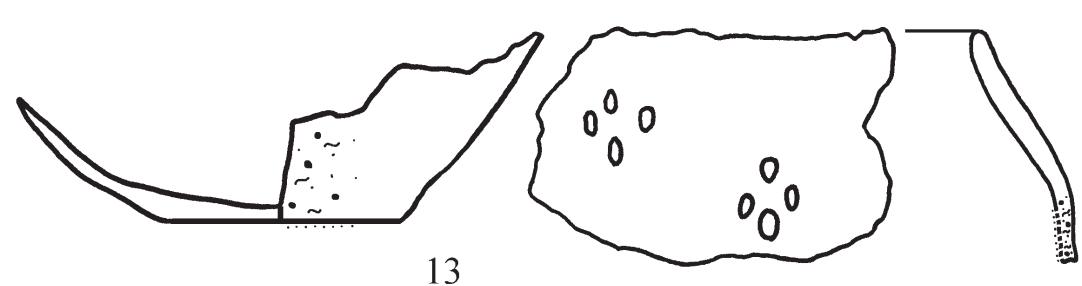

14

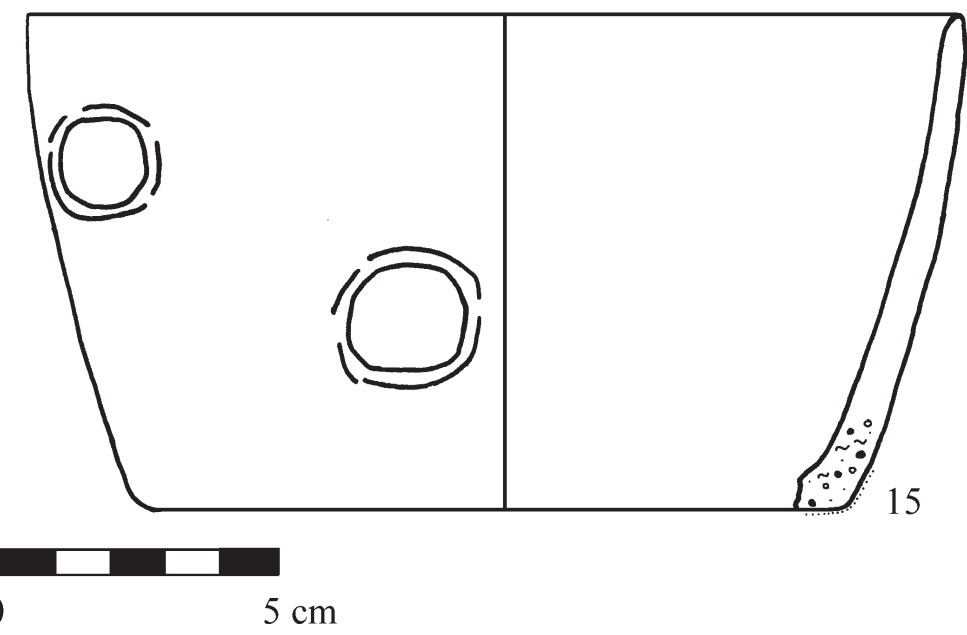

Obr. 16. Nová Ves u Oslavan - „Kopaniny”. Výběr keramického materiálu (kresba: A. Čerevková, H. Koubková).

Fig. 16. Nová Ves u Oslavan - "Kopaniny". Selection of ceramic finds (drawing: A. Čerevková, H. Koubková). 
není na území Moravy mnoho, známé jsou např. exempláře z Boskovštejna či Bojanovic (Podborský 1985, 97).

\section{Diskuze}

V současné době je z okolí Nové Vsi známo kolem dvacítky lokalit kultury s MMK, respektive jejího staršího stupně (Kuča et al. 2012b, 111). Osídlení je v dané oblasti východní části Jevišovické pahorkatiny vázáno především na toky velkých řek (Jihlava, Oslava, Rokytná) a bylo již od staršího stupně kultury s MMK relativně husté (Kazdová 1997).

$\mathrm{V}$ bezprostřední blízkosti sídliště u Nové Vsi byl nejintenzivněji osídlen katastr Oslavan, kde evidujeme celkem šest poloh, včetně jedné výšinné, datovaných rámcově do staršího i mladšího stupně. Doklady osídlení lidu kultury s MMK byly dále identifikovány na katastru Hrubšic, Padochova, Budkovic (Koštuřik 1989, 40-49), Ivančic (Kos 2014, 161) a nově také Neslovic (obr. 11; Hájek et al. v tisku).

Doklady osídlení polohy „Kopaniny” u Nové Vsi u Oslavan vykazují v rámci sledované kultury dlouhodobý charakter. Podle povahy získaného materiálu se jedná o lokalitu osídlenou po značnou část vývoje kultury s MMK, přičemž těžiště tohoto osídlení zřejmě spočívalo v obou fázích staršího stupně. Mladší stupeň je zastoupen o něco méně; lze předpokládat, že počátkem mladšího stupně začíná osídlení postupně vyznívat. Takto dlouhodobě osídlená lokalita kultury s MMK, v tomto případě navíc s předchozí návazností na kultury s LnK i VpK, představuje v užší i širší sídelní oblasti ojedinělý jev. Existují nicméně alespoň přibližné analogické situace reprezentované lokalitami Brno-Žebětín - „Na Drdi,” (Kuča - Kazdová - Přichystal 2005; Trampota - Kuča 2011) a Popůvky - „Pod Šípem, a „Panské Nivy, (Palečková 2009), kde byly doloženy fáze Ia a Ib i staroneolitické osíd- lení. Tyto lokality se nacházejí v krátké vzdálenosti od Nové Vsi (cca 15 km vzdušnou čarou) a nelze tedy vyloučit jejich vzájemnou interakci. Další závěry by bylo možné vyvodit až v souvislosti s výsledky analýzy kamenné štípané industrie, zejména $\mathrm{z}$ hlediska jejího surovinového zastoupení. Dané informace by rovněž mohly napomoci při rekonstrukci povahy dálkových kontaktů a ukotvení lokality v rámci struktury osídlení. Dále by bylo jistě zajímavé sledovat charakter vnitřní zástavby sídliště, což by pomohlo odhalit kontinuitu osídlení v průběhu existence osady kultury s MMK a ostatních zastoupených kultur. Bez průvodní dokumentace nálezových okolností je však tato otázka bohužel neřešitelná. V souvislosti s aktuálně sledovanou problematikou vztahu mezi absolutní a dosud platnou relativní chronologií kultury s MMK (Kuča et al. 2012a) nelze v případě Nové Vsi u Oslavan vyslovit spolehlivé závěry, a to především z důvodu absence informací o vzájemném prostorovém postavení nálezů fází Ia a Ib. Tyto fáze se podle výše zmíněné studie mají vylučovat spíše $\mathrm{v}$ geografickém měřítku, což v tomto případě nelze spolehlivě prokázat.

\section{Závěry}

Na základě dosud získaných archeologických nálezů lze polohu „Kopaniny“ u Nové Vsi u Oslavan označit jako poměrně intenzivně osídlenou polykulturní lokalitu. Svého vrcholu dosáhlo osídlení pravděpodobně v závěru vývoje kultury s LnK (šárecký stupeň); neméně významné však byly rovněž aktivity lidu kultury s MMK, jejichž doklady zde zůstaly zachovány a byly získány především v podobě obsáhlého souboru keramiky, čítajícího celkem 2242 fragmentů. Tento soubor byl systematicky analyzován zejména za účelem chronologického postavení lokality. Zásadním problémem při rozboru materiálu byla chybějící dokumentace k nálezovým situacím. 

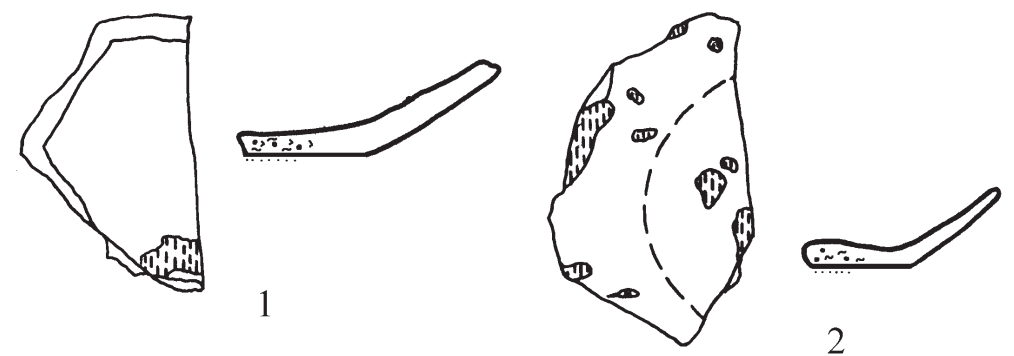

2
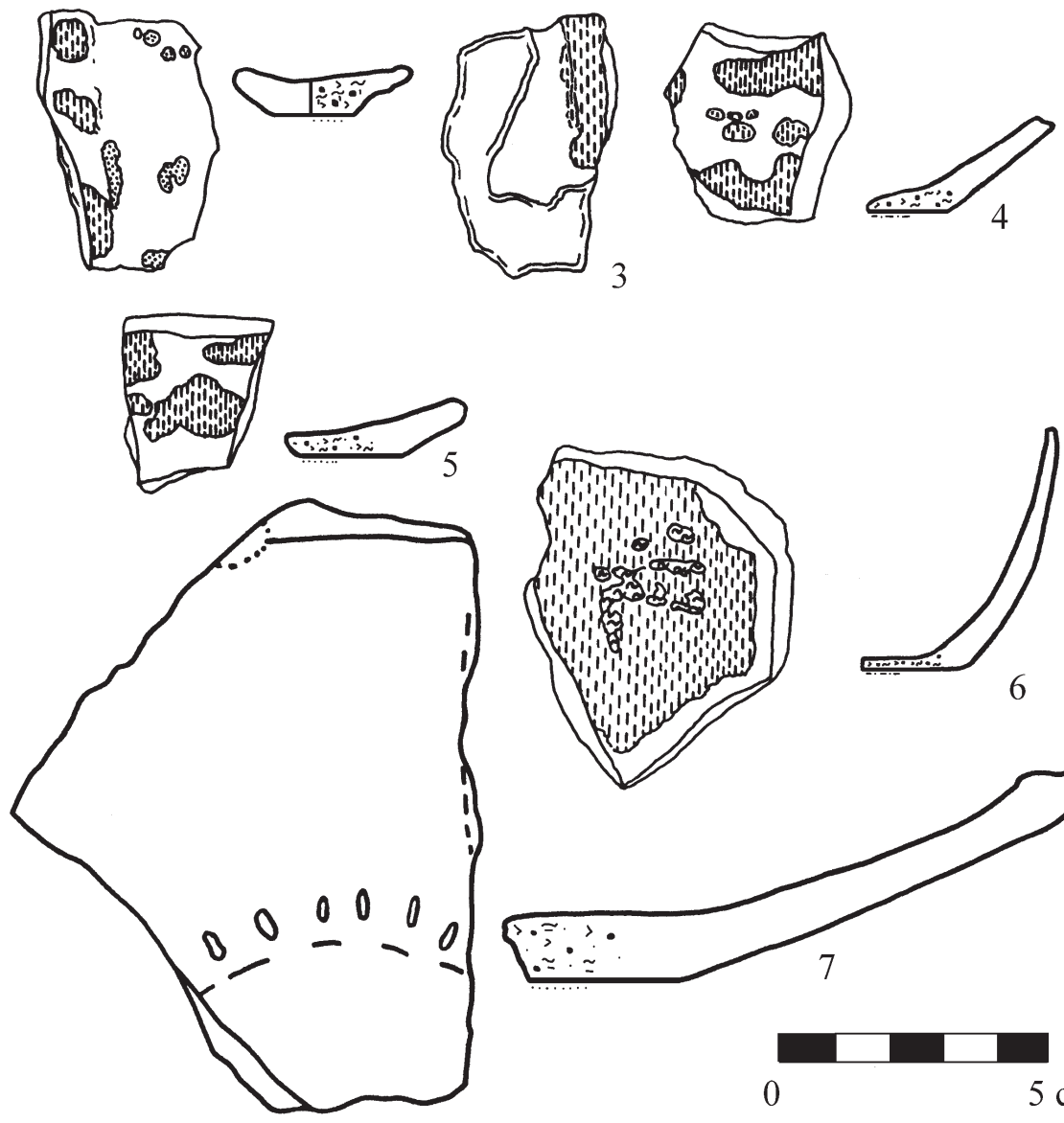

6

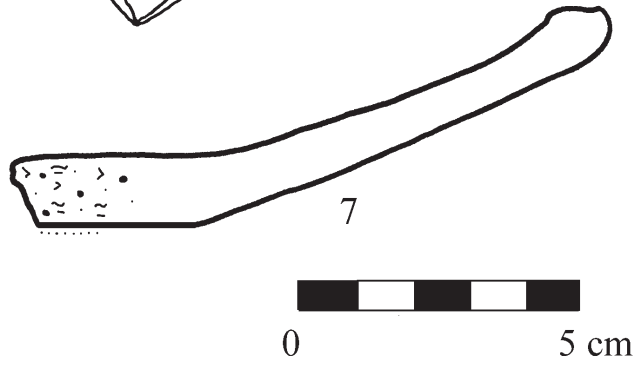

Obr. 17. Nová Ves u Oslavan - „Kopaniny”. Výběr keramického materiálu (kresba: A. Čerevková, H. Koubková).

Fig. 17. Nová Ves u Oslavan - "Kopaniny". Selection of ceramic finds (drawing: A. Čerevková, H. Koubková). 


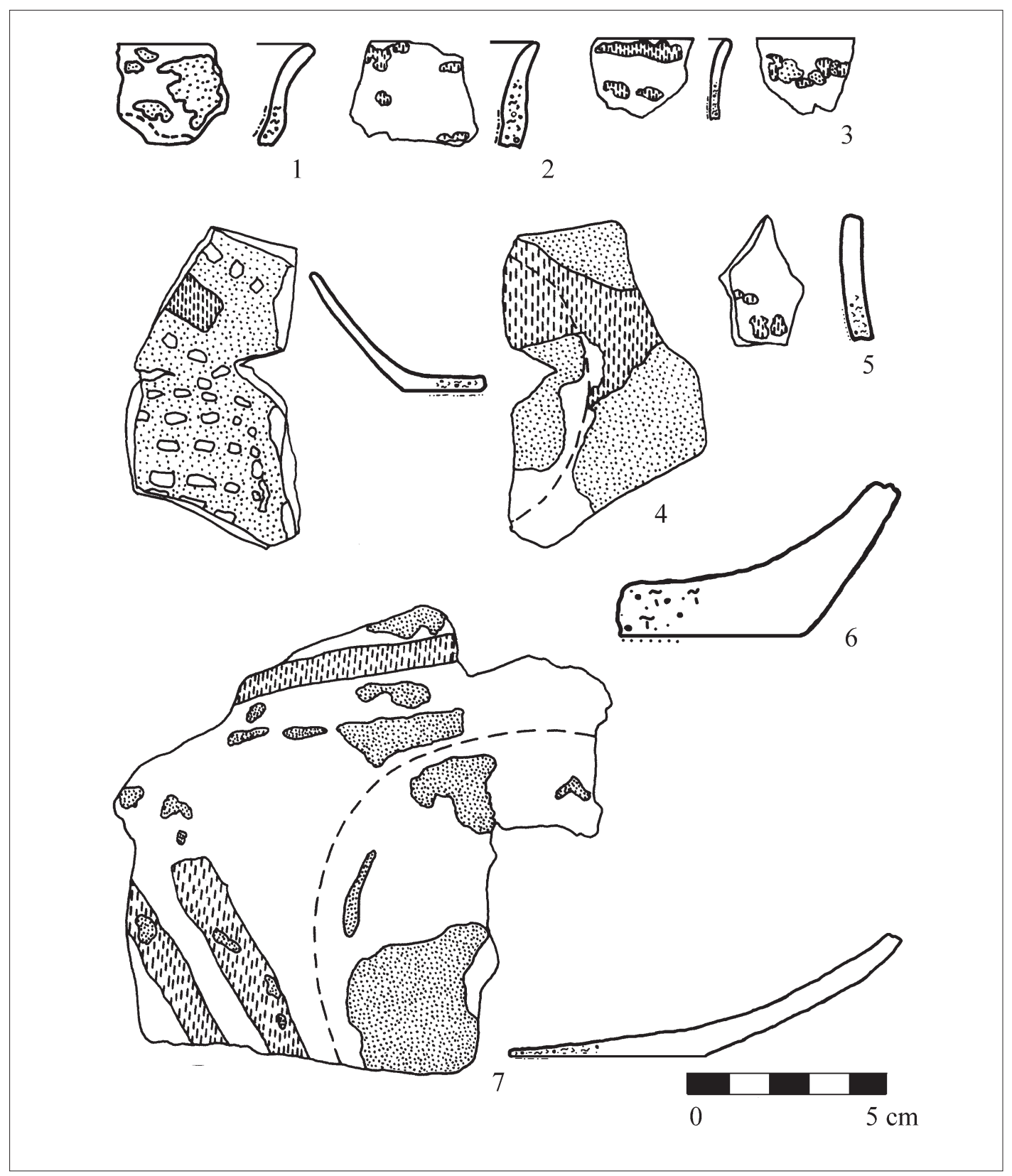

Obr. 18. Nová Ves u Oslavan - „Kopaniny”. Výběr keramického materiálu (kresba: A. Čerevková, H. Koubková).

Fig. 18. Nová Ves u Oslavan - "Kopaniny". Selection of ceramic finds (drawing: A. Čerevková, H. Koubková). 
Většina nálezů byla totiž získána během meziválečného období a průvodní dokumentace se do dnešní doby nedochovala. Nálezový soubor tak nelze postavit do souvislosti s prostorovými strukturami sídliště a lze jej hodnotit pouze po kvantitativní stránce.

Z tohoto hlediska lze o získané kolekci vyslovit několik základních poznatků: celý soubor byl poměrně hodně fragmentární, o čemž vypovídá nejen četnost jednotlivých velikostních kategorií, ale také skutečnost, že bylo možné s jistotou identifikovat pouze devět keramických skupin (hrnce a jiné hrncovité tvary, poháry a pohárky, mísy a misky, mísy na nožce, naběračky, miniaturní nádobky a plastiky). Na některých jiných lokalitách bylo přitom možné vyčlenit až osmnáct keramických skupin (Hluboké Mašůvky; Hájek 2013, 100-101). Nejpočetnější byla skupina hrnců a hrncovitých nádob, následovala skupina pohárů/pohárků a mís/misek. Ostatní skupiny byly zastoupeny výrazně méně. Problematické bylo odlišení mís a mís na nožce, pokud není zachována přechodová partie mísy v nožku nebo fragment nožky, jsou od sebe těžko rozeznatelné. Pro celý soubor, zejména pro skupinu hrnců a hrncovitých nádob, byla př́íznačná dodatečná příměs slídy do keramického těsta. Velice drobná zrnka slídy se objevila také v jinak jemné, plavené hmotě použité na výrobu pohárků. Kromě toho se vyskytly také stopy organických příměsí ve formě různých otisků a negativů, a to nejčastěji u hrnců a jiných hrncovitých nádob. Značná pozornost byla věnována výzdobě keramiky. Rozbor výzdobných prvků se stal hlavním vodítkem pro stanovení relativní chronologie souboru. Výzdoba byla provedena nejčastěji malováním, o něco méně časté byly vhloubené a plastické prvky. Využití všech druhů výzdoby se vyskytlo pouze na hrncích a hrncovitých nádobách, mísách/miskách a pohárech/pohárcích.

Osídlení kultury s moravskou malovanou keramikou v poloze „Kopaniny” u Nové Vsi lze, vzhledem k povaze obsáhlého keramického souboru, považovat za poměrně intenzivní a zároveň relativně dlouhodobé. Především na základě výzdoby zde byly s jistotou rozpoznány tři fáze vývoje dané kultury: Ia, Ib a mladší stupeň kultury s MMK. Zajímavou otázkou by jistě bylo sledování jejich vzájemných vztahů, a to z hlediska vertikální i horizontální stratigrafie. Odlišení jednotlivých částí nálezového celku podle jednotlivých parcel (polí) poskytuje jen velmi nejasnou představu o velikosti sídliště v průběhu jednotlivých fází osídlení a jejich případné vzájemné superpozici.

Opakované osídlování lokality jistě souvisí s její výhodnou polohou na mírně se svažujícím břehu řeky Oslavy. Důležitá byla také strategická pozice sídliště v síti okolních lokalit. Je pravděpodobné, že sídliště kultury s MMK v Nové Vsi mohlo dosahovat stejného významu jako lokality Znojmo-Novosady, Hluboké Mašůvky (Hájek 2013) či Jaroměřice nad Rokytnou (Koštuřik 1979). Pro bližší rekonstrukci postavení lokality by bylo určitě přínosem doplnit informace o technologických i typologických vlastnostech štípané industrie a také použitých surovinách. Tyto údaje by mohly alespoň trochu osvětlit postavení lokality v kontextu okolního osídlení. Absence poznatků o rozloze a vnitřní struktuře sídliště však zůstává stále překážkou v zodpovězení této otázky. Možným řešením by byla realizace revizního výzkumu, ideálně za využití nedestruktivních metod, eventuálně v kombinaci se systematickou sondáží. Jeho provedení však brání především nedostatek prostředků.

\section{Literatura}

Bartik, J. 2015: Sídelní a socioekonomické aspekty lengyelské kultury v prostoru nejzápadnější Moravy. Rukopis magisterské diplomové práce uložený v knihovně Ústavu archeologie a muzeologie FF MU v Brně. 
Hájek, Z. 2013: Hluboké Mašůvky, Znojmo Novosady - významná sídliště kultury s moravskou malovanou keramikou na Moravě. Rukopis disertační práce uložený v knihovně Ústavu archeologie a muzeologie FF MU v Brně.

Hájek, Z. - Humpolová, A. - Čerevková, A. 2014: Polykulturní lokalita Nová Ves u Oslavan. AMM Sci. Soc. XCIX: 2, 211-225.

Hájek, Z. - Bartik, J. - Čerevková, A. - Koubková, H. v tisku: Neolitické a eneolitické osídlení Neslovicka (okres Brno-venkov).

Jaroš, J. 1972: Šárecký stupeň kultury s lineární keramikou na Moravě, díl I.-III. Rukopis magisterské diplomové práce uložený v knihovně Ústavu archeologie a muzeologie FF MU v Brně.

Kazdová, E. 1983: K vybraným chronologickým znakům kultury s MMK. Sborník prací filozofické fakulty brněnské univerzity E 28, 113-126.

Kazdová, E. 1997: Poznámky k postlineárnímu neolitu na jihozápadní Moravě. In: Z pravěku do středověku. Sborník k 70. narozeninám Vladimíra Nekudy. Brno, 36-41.

Kos, P. 2014: Ivančice (okr. Brno-venkov). Přehled výzkumů 55-1, Brno, 161.

Kovárnik, J. 2005: Mladší moravská malovaná keramika z Hnánic u Znojma. In: Cheben, I. (ed.), Otázky neolitu a eneolitu našich krajín 2004, Nitra, 161-184.

Koštuřik, P. 1977-1978: Neolitické sídliště v poloze „Kopaniny“ u Nové Vsi, okr. Brno venkov. Sborník prací filozofické fakulty brněnské univerzity E 22-23, 77-91.

Koštuřik, P. 1979: Neolitické sídliště s moravskou malovanou keramikou u Jaroměřic n. R., StAÚ Brno VII/1, Praha.

Koštuřı́, P. 1989: Neolit. In: Belcredi, L. (ed.), Archeologické lokality a nálezy okresu Brno-venkov. Brno.

Kuča, M. - Kazdová, E. - Přichystal, A. 2005: Sídliště kultury s moravskou malovanou keramikou staršího stupně v Brně - Žebětíně, Pravěk NŘ 13, 2003, 37-84

Kuča, M. - Kovár̆, J. J. - Nývltová Fišáková, M. - Škrdla, P. - Prokeš, L. - Vaškových, M. - Schenk, Z. 2012a:
Chronologie neolitu na Moravě: předběžné výsledky. Přehled výzkumů 53-1, 51-64.

Kuča, M. - Nývltová Fišáková, M. - Škrdla, P. - Vokáčc, M. 2012b: Lokalita staršího stupně kultury s moravskou malovanou keramikou v Březníku na Českomoravské vrchovině. Sborník prací filozofické fakulty brněnské univerzity M 17, 95-120.

Langweilová, P. 2008: Naběračky lidu s moravskou malovanou keramikou z lokality Těšetice-Kyjovice. Rukopis bakalářské diplomové práce uložený v knihovně Ústavu archeologie a muzeologie FF MU v Brně.

Němejcová-Pavúková, V. 1998: Praveké dejiny Svodína. Svodín.

Palečková, O. 2009: Sídliště s moravskou malovanou keramikou lengyelské kultury v Popůvkách. Rukopis magisterské diplomové práce uložený v knihovně Ústavu archeologie a muzeologie FF MU v Brně.

Podborský, V. - Kazdová, E. - Koštuřik, P. - Weber, Z. 1977: Numerický kód moravské malované keramiky. Brno.

Podborský, V. 1983: K metodice a možnostem studia plastiky lidu s moravskou malovanou keramikou. Sborník prací filozofické fakulty brněnské univerzity E 28, 7-93.

Podborský, V. 1985: Těšetice-Kyjovice II. Figurální plastika lidu s moravskou malovanou keramikou. Brno.

Prokeš, L. - Procházková, M. - Kuča, M. - Parma, D. Fojtik, P. - Humpola, D. 2011: Identifikace tmavých smolných hmot z neolitických nálezů na Moravě. Sborník prací filozofické fakulty brněnské univerzity M 14-15, 113-130.

Trampota, F. - Kuča, M. 2011: Brno-Žebětín - „Na Drdi“. Neolitická lokalita v kontextu Brněnska. Sborník prací filozofické fakulty brněnské univerzity M 14-15, 87-112.

Vostrovská, I. 2010: Keramika ze sídliště kultury lineární v Těšeticích-Kyjovicích „Sutnách“. Rukopis magisterské diplomové práce uložený v knihovně Ústavu archeologie a muzeologie FF MU v Brně. 


\section{Settlement of the Moravian Painted Ware Culture in Nová Ves near Oslavany (Brno-venkov district)}

Based on the archaeological findings gained from the "Kopaniny" site (in the municipality of Nová Ves village) it is possible to describe the area as an intensively settled polycultural site. The peak of the settlement falls into the latest phase of the Linear Pottery Culture (so-called Sarka type). The subsequent settlement of the Moravian Painted Pottery Culture is significant as well.

The resettlement of the site can be explained by the site's strategic position on the steep bank of the Oslava River. It is probable that the "Kopaniny" site is as significant as Znojmo-Novosady site, Hluboké Mašůvky site and Jaroměřice nad Rokytnou site. It would be valuable to complete the information about the settlement from the point of view of technology and typology of the chipped stone industry and its raw materials.

The majority of the collection is constituted by the ceramic material (2242 pottery sherds). This paper describes the analysis of the collection in order to designate the precise chronology of the site. Very problematic is the fact that there was no documentation for the depositional context; therefore we could evaluate the set of the findings finds only quantitatively.

The result of the analysis is: the ceramic assemblages are very fragmentary to designate nine ceramic groups (pots and others pot-shaped vessels, beakers and small beakers, bowls and footed bowls, ladles, miniature vessels and figurines). The most dominant group was that of the pots and others pot-shaped vessels, followed by beakers and bowls. The other groups represented in significantly lower number. It was very difficult to distinguish between bowls and footed bowls, especially when the part of transition from the bowl to a foot or a fragment of the foot has not been preserved.

It is worth mentioning that throughout the set mica inclusions appeared mainly in the case of pots and other pot-shaped vessels. Mica inclusions were observed in beakers made from a very fine ware as well. Apart from mica inclusions admixtures of organic matter - in the form of various imprints and negatives - were identified in the pot group.

Another category, which was analyzed carefully, was decoration. The decoration motif breakdown was set a guideline for the set's relative chronology determination. The dominant technique is painting followed by incision and plastic decoration. The decoration occurred only in the pots and other pot-shaped vessel group, bowl group and beaker group. With regard to the decoration three phases of pottery development have been recognized: Ia, Ib and the latest phase of the Moravian Painted Pottery Culture. 


\section{Mgr. Zdeněk Hájek, Ph.D.}

- Archeologický ústav, Historické muzeum, Moravské zemské muzeum,

Zelný trh 6, 65937 Brno, Česká republika zhajek@mzm.cz

\section{PhDr. Alena Humpolová}

- Archeologický ústav, Historické muzeum, Moravské zemské muzeum,

Zelný trh 6, 65937 Brno, Česká republika humpolova@mzm.cz

\section{Mgr. Alžběta Čerevková}

- Ústav archeologie a muzeologie, Filozofická fakulta, Masarykova univerzita, Arna Nováka 1, 60200 Brno, Česká republika; 330952@mail.muni.cz 